\title{
Tethering versus Non-Coordination of Hydroxy and Methoxy Side Chains in Arene Half Sandwich Dichloro Ruthenium Complexes
}

\author{
Jadranka Čubrilo ${ }^{\mathrm{a}, \mathrm{h}, *}$, Ingo Hartenbach ${ }^{\mathrm{b}}$, Thomas Schleid ${ }^{\mathrm{b}}$, and Rainer F. Winter*,a \\ Regensburg, Institut für Anorganische Chemie der Universität
}

\section{Dedicated to Professor Henri Brunner on the Occasion of his $70^{\text {th }}$ Birthday}

\begin{abstract}
We are reporting on the hydroxyalkyl appended arene ruthenium half sandwich complexes $\left[\left\{\eta^{6}-\mathrm{C}_{6} \mathrm{H}_{5}\left(\mathrm{CH}_{2}\right)_{\mathrm{n}} \mathrm{OH}\right\} \mathrm{RuCl}_{2}\right]$ $(\mathrm{n}=2,3)$ and the methyl ether of the hydroxypropyl derivative. Most significantly, a structural comparison between the hydroxypropyl complex 1a and its methyl ether 2a reveals, that the latter adopts the conventional dichloro bridged dimeric structure while 1a is a monomer. Coordinative saturation of the ruthenium centre is achieved by intramolecular coordination of the appended hydroxy function, thus rendering the functionalized arene an eight electron donor chelate ligand. The structure is further stabilized by intermolecular $\mathrm{OH}^{\cdots} \mathrm{Cl}$ hydrogen bridges between a terminal
\end{abstract}

\section{Introduction}

Transition metal half-sandwich complexes with potentially coordinating groups appended to the cyclic perimeter are receiving increasing attention as a special class of complexes bearing hemilabile ligands. The dangling functionality may serve to stabilize otherwise elusive and coordinatively unsaturated species by forming an additional coordinate bond to the metal atom, thus rendering the respective arene a tetradentate chelate ligand. Recent work on arene halfsandwich complexes of ruthenium has mainly concentrated on tethered phosphine [1-9] or arsine [6] groups which were found to readily coordinate to the metal atom. Appended phosphine groups may even serve as a "Trojan horse" by anchoring the functionalized arene to the metal atom prior to $\pi$-coordination. Arene displacement in complexes $\left[\left(\eta^{6}\right.\right.$-arene $) \mathrm{RuCl}_{2}\left\{\mathrm{PR}_{2}\left(\mathrm{CH}_{2}\right)_{12}\right.$ aryl $\left.\}\right]$ is then achieved by an either thermally $[1,2,4,8]$ or oxidatively induced substitution step [1]. These studies have also disclosed, that tethered coordinating groups may endow such complexes with reactivities that differ significantly from their non-tethered congeners $[10,11]$. Much less work has been done on com-

\footnotetext{
* Prof. Dr. Rainer F. Winter

a) Institut für Anorganische Chemie der Universität

Universitätsstraße 31

D-93040 Regensburg

e-mail: rainer.winter@chemie.uni-regensburg.de;

b) Institut für Anorganische Chemie der Universität Stuttgart Pfaffenwaldring 55

D-70569 Stuttgart
}

chloride ligand of one and the coordinated hydroxy group of a neighbour molecule, resulting in a sheet structure. These intermolecular interactions appear to be even stronger in the hydroxyethyl analogue. Several phosphine adducts have been prepared from the hydroxy or alkoxy functionalized $\left[\left(\eta^{6} \text {-arene }\right) \mathrm{RuCl}_{2}\right]_{\mathrm{n}}$ precursors, including water soluble $\mathrm{P}\left(\mathrm{CH}_{2} \mathrm{OH}\right)_{3}$ adducts. Electrochemical properties of the phosphine adducts and of the dichloro bridged aryl ether complex $2 \mathrm{a}$ are also discussed.

Keywords: Ruthenium; Crystal Structure; H-Bridge; Electrochemistry

plexes of arenes with oxygen containing groups such as ethers or the hydroxy function [12]. Kurosawa and co-workers have briefly reported on $\left[\left\{\eta^{6}-\mathrm{C}_{6} \mathrm{H}_{5}\left(\mathrm{CH}_{2}\right)_{\mathrm{n}} \mathrm{OH}\right\} \mathrm{RuCl}_{2}\right]$ $(\mathrm{n}=2,3)$ and assumed them to possess dimeric structures with two chloride bridges connecting the $\left\{\left(\eta^{6}\right.\right.$-arene $\left.) \mathrm{RuCl}\right\}$ units as it is ususally found for this type of complexes. No analytical data were, however, provided and no further evidence for these conclusions has been presented $[13,14]$. The cationic derivatives $\left[\left\{\eta^{6}: \eta^{1}-\mathrm{C}_{6} \mathrm{H}_{5}\left(\mathrm{CH}_{2}\right)_{3} \mathrm{OH}\right\} \mathrm{Ru}\left(\mathrm{PR}_{3}\right) \mathrm{Cl}\right]^{+}$ $\left(\mathrm{PR}_{3}=\mathrm{PPh}_{3}, \mathrm{PEt}_{3}\right)$ and $\left[\left\{\eta^{6}: \eta^{1}-\mathrm{C}_{6} \mathrm{H}_{5}\left(\mathrm{CH}_{2}\right)_{3} \mathrm{OH}\right\} \mathrm{RuL}_{2}\right]^{2+}$, where $\mathrm{L}_{2}$ is a chelating dinitrogen donor such as 2,2'-bipyridine, 1,10-phenanthroline or a bisoxazolonyl ligand, clearly show the coordinating ability of the hydroxy group. According to NMR studies, the cationic derivatives preserve their tethered structures with the oxygen atom bonded to the metal even in methanolic solution [14]. The utility of those complexes for cycloisomerization and ring closing metathesis of diolefins has recently been demonstrated [15]. Additional work made use of the reactivity inherent to the hydroxy function and its conversion to a diaryl phosphinic ester by reaction with $\mathrm{Ph}_{2} \mathrm{PCl}$ [14], deprotonation to a coordinating alcoholate [14], and esterification by reaction with ferrocene carboxylic acids [16] have been reported.

As a part of our ongoing programme on using arene dichloro ruthenium complexes as templates for cyclooligomerization and co-cyclization reactions [17] we have also prepared and investigated ruthenium dichloro half-sandwich complexes with the hydroxy- and methoxypropyl side chain (1a, 2a) as well as the shorter chain ethyl alcohol 3a. We here report the full characterization of these complexes along with the crystal structures of the propyl methyl ether 
and the hydroxypropyl derivatives. Contrary to previous reports, the latter complex turned out to be monomeric in the solid state with the hydroxy function coordinated to the metal atom and an intermolecular hydrogen bridge between the $\mathrm{OH}$ proton and a chloride ligand of a neighbouring molecule. We have also prepared the triisopropylphosphine adducts of complexes 1a - $\mathbf{3} \mathbf{a}$ as well as the tricyclohexylphosphine adducts of $1 \mathrm{a}$ and $2 \mathrm{a}$ and the $\mathrm{P}\left(\mathrm{CH}_{2} \mathrm{OH}\right)_{3}$ containing complexes 1d,e. Voltammetric data on most complexes are provided as well.

\section{Results and Discussion}

\section{The dichloro complexes 1a-3a}

The synthesis of the functionalized arene complexes 1a, 2a and $3 \mathbf{a}$ followed the established methods $[14,18]$. First the parent arene was reduced to the corresponding cyclohexadiene under Birch conditions [19]. The cyclohexadienes were then reacted with commercial hydrated $\mathrm{RuCl}_{3}$ where they simultaneously serve as reductant and ligand to give the respective arene complexes $\left[\left\{\eta^{6}-\mathrm{C}_{6} \mathrm{H}_{5}\left(\mathrm{CH}_{2}\right)_{11} \mathrm{OR}\right\} \mathrm{RuCl}_{2}\right]$ $(\mathrm{n}=3, \mathrm{R}=\mathrm{H}: \mathbf{1 a}, \mathrm{R}=\mathrm{Me}: \mathbf{2} \mathbf{a} ; \mathrm{n}=2, \mathrm{R}=\mathrm{H}: \mathbf{3 a})$ in good yields. These complexes were obtained as orange solids by slowly cooling the concentrated mother liquors (1a, 2a) or as an orange brown powdery precipitate (3a). The hydroxy and methoxy substituted congeners 1a and 2a show markedly differing solubilities. While the ether is readily soluble in moderately polar organic solvents such as chloroform and methylene chloride, the hydroxypropyl derivative 1a is only moderately soluble in $\mathrm{CH}_{2} \mathrm{Cl}_{2}$. The shorter chain hydroxyethyl analogue $3 \mathbf{a}$ finally is very sparingly soluble even in boiling 1,2-dichloroethane and requires coordinating solvents like dimethylsulfoxide or dimethylformamide to allow for NMR spectroscopic characterization. This already points to the presence of significant intermolecular contacts via hydrogen bridges sustained by the $\mathrm{OH}$ group as the donor. In these donor solvents the arene protons and those of the ethyl side chain of 3 a give rise to sharp, well resolved resonance signals. The ${ }^{13} \mathrm{C}$ NMR spectra are likewise unsuspicious. Asides from disrupting the intermolecular hydrogen bonds, donor solvents may also coordinate to the metal atom and cleave the $\mathrm{Ru}-\mathrm{Cl}$ bridges of $\left[\left(\eta^{6} \text {-arene }\right) \mathrm{RuCl}_{2}\right]_{2}$ dimers or displace other donors. Dichloro bridged diruthenium complexes $\left[\left(\eta^{6} \text {-arene }\right) \mathrm{RuCl}_{2}\right]_{2}$ are known to form monomeric complexes $\left[\left(\eta^{6}\right.\right.$-arene $\left.) \mathrm{RuCl}_{2}(\mathrm{~L})\right]$, [( $\eta^{6}$-arene $)$ $\left.\mathrm{RuCl}(\mathrm{L})_{2}\right]^{+}$or $\left[\left(\eta^{6} \text {-arene }\right) \mathrm{Ru}\left(\mathrm{L}_{3}\right)\right]^{2+}$ in strong donor solvents $\left(\mathrm{L}=\right.$ dmso, dmf, $\left.\mathrm{OH}_{2}\right)[20-22]$. As positive charge accumulates upon chloride substitution, the resonance signals of the coordinated arene are commonly shifted to lower field [14, 21, 22]. While the exact nature of the species present in dmso or dmf solutions of the hydroxyethylbenzene dichloro complex 3 a remains an open issue, it is still interesting to note a low field shift of 0.30 to $0.35 \mathrm{ppm}$ for the aryl protons when $d m f-d_{7}$ is replaced by dmso- $_{6}$. No such shift differences are observed for the protons of the hydroxyalkyl side chain. Similar trends also prevail for $\mathbf{1 a}$.
Here, a strong donor solvent is also likely to interfere with the intramolecular coordination of the hydroxy group, as it is present in the solid state (see following section) and very likely also in a non-coordinating solvent like $\mathrm{CD}_{2} \mathrm{Cl}_{2}$.

\section{Crystallographic investigation of $1 \mathrm{a}$ and $2 \mathrm{a}$}

Crystals suitable for crystallographic determinations of the molecular structures have been obtained for the propyl methyl ether as well as the hydroxypropyl benzene derived complexes by slowly cooling a hot saturated solution of the respective complex in ethanol. Plots of the molecular structures are provided as Figures 1 and 2. Relevant data per-

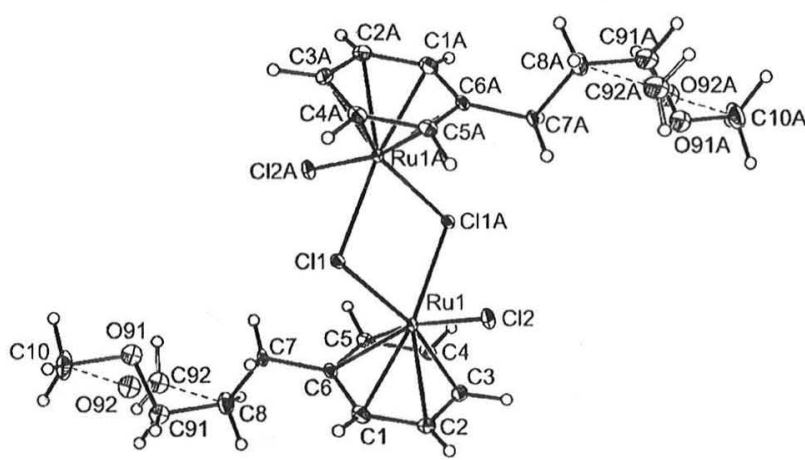

Figure 1 Molecular structure of $\left[\left(\eta^{6}-\mathrm{C}_{6} \mathrm{H}_{5}\left(\mathrm{CH}_{2}\right)_{3} \mathrm{OMe}\right) \mathrm{RuCl}_{2}\right]_{2}$ (2a) in the crystal.

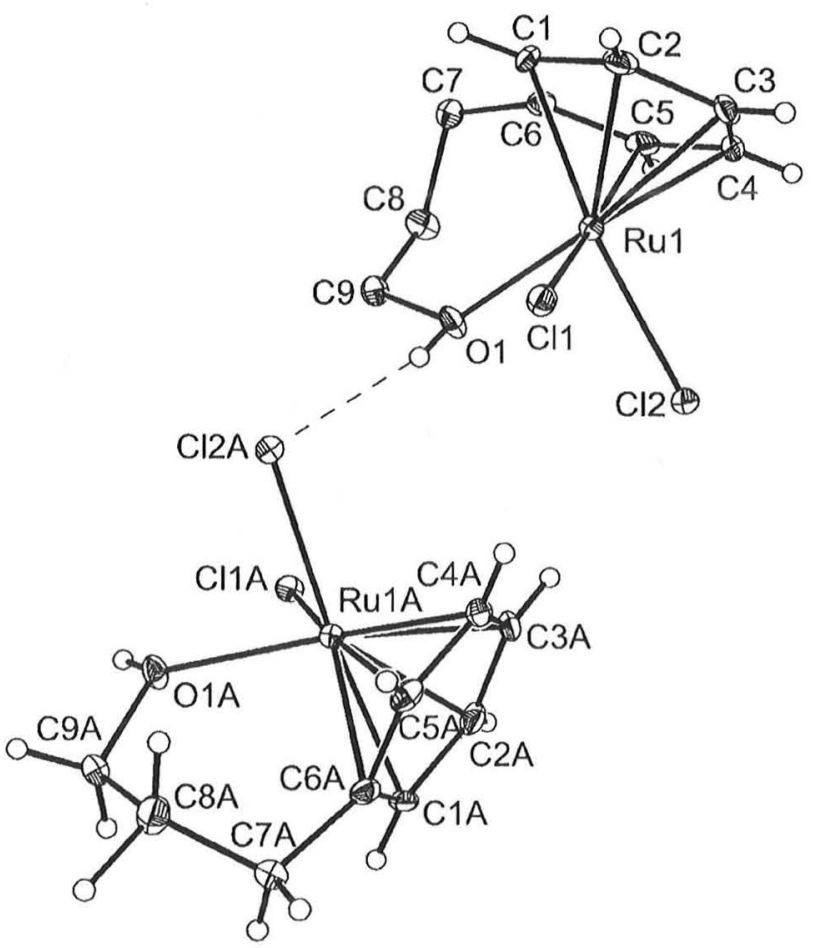

Figure 2 Molecular structure of $\left[\left(\eta^{6}-\mathrm{C}_{6} \mathrm{H}_{5}\left(\mathrm{CH}_{2}\right)_{3} \mathrm{OH}\right) \mathrm{RuCl}_{2}\right](\mathbf{1 a})$ in the crystal, showing a $\mathrm{OH} \cdots \mathrm{Cl}$ bonded pair. 
Table 1 Data pertinent to the data collection and structure solution of $1 \mathrm{a}$ and $2 \mathrm{a}$.

\begin{tabular}{|c|c|c|}
\hline & $2 \mathrm{a}$ & 1a \\
\hline Empirical formula & $\mathrm{C}_{20} \mathrm{H}_{28} \mathrm{Cl}_{4} \mathrm{O}_{2} \mathrm{Ru}_{2}$ & $\mathrm{C}_{9} \mathrm{H}_{12} \mathrm{Cl}_{2} \mathrm{ORu}$ \\
\hline Formula weight & 644.36 & 308.16 \\
\hline Temperature / K & $100(2)$ & $100(2)$ \\
\hline$\lambda / \AA^{\alpha}$ & 0.71073 & 0.71073 \\
\hline Crystal system & triclinic & monoclinic \\
\hline Space group & $\mathrm{P} \overline{1}$ & $\mathrm{C} 2 / \mathrm{c}$ \\
\hline Crystal size / mm & $0.3 \times 0.3 \times 0.2$ & $0.25 \times 0.2 \times 0.2$ \\
\hline \multicolumn{3}{|l|}{ Unit cell dimensions } \\
\hline a / & $7.4241(2)$ & $13.6525(9)$ \\
\hline b / & $7.7451(3)$ & $9.3455(8)$ \\
\hline $\mathrm{c} / \mathrm{A}$ & $10.7216(3)$ & $15.7922(11)$ \\
\hline$\alpha / \operatorname{deg}$ & $108.792(2)$ & \\
\hline$\beta / \operatorname{deg}$ & $92.177(2)$ & $90.47(1)$ \\
\hline$\gamma / \operatorname{deg}$ & $103.886(2)$ & \\
\hline $\mathrm{Z}$ & 1 & 8 \\
\hline Volume / $\AA^{3}$ & $562.10(3)$ & $2014.8(3)$ \\
\hline$\rho_{\text {calcd }} / \mathrm{g} \cdot \mathrm{cm}^{-3}$ & 1.904 & 2.032 \\
\hline Theta range / deg & $2.02-27.51$ & $3.68-28.29$ \\
\hline Limiting indices & $\begin{array}{l}-8 \leq \mathrm{h} \leq 9 \\
-10 \leq \mathrm{k} \leq 10 \\
-13 \leq 1 \leq 13\end{array}$ & $\begin{array}{l}-18 \leq \mathrm{h} \leq 18, \\
-12 \leq \mathrm{k} \leq 10, \\
-21 \leq 1 \leq 19\end{array}$ \\
\hline Collected reflections & 12915 & 11060 \\
\hline Unique reflections & 2573 & 2483 \\
\hline $\mathrm{R}$ (int) & 0.0946 & 0.0925 \\
\hline$\mu\left(\mathrm{Mo}^{\prime} \mathrm{K}_{\mathrm{x}}>\right) / \mathrm{mm}^{-1}$ & 1.833 & 2.041 \\
\hline R1 (all data) & 0.0377 & 0.0704 \\
\hline wR2 (all data) & 0.0952 & 0.0871 \\
\hline GooF on $F^{2}$ & 1.171 & 1.088 \\
\hline $\mathrm{F}(000)$ & 320 & 1216 \\
\hline Largest diff. peak / hole & $0.549 /-1.197$ & $0.730 /-0.901$ \\
\hline
\end{tabular}

Table 2 Selected bond lengths in $\AA$ and angles in deg. for complexes $1 \mathbf{a}$ and $2 \mathbf{a}$.

\begin{tabular}{|c|c|c|c|}
\hline \multicolumn{2}{|l|}{$2 a$} & \multicolumn{2}{|l|}{$1 \mathrm{a}$} \\
\hline $\mathrm{Rul}-\mathrm{Cll}$ & $2.4427(8)$ & $\mathrm{Rul}-\mathrm{Cll}$ & $2.409(1)$ \\
\hline $\mathrm{Rul} \cdots \mathrm{Cl} 1 \mathrm{~A}$ & $2.4481(8)$ & $\mathrm{Ru} 1 \cdots \mathrm{Cl} 2$ & $2.421(1)$ \\
\hline $\mathrm{Ru} 1-\mathrm{Cl} 2$ & $2.4067(8)$ & $\mathrm{Rul}-\mathrm{O} 1$ & $2.154(3)$ \\
\hline $\mathrm{Rul}-\mathrm{Cl}$ & $2.178(3)$ & $\mathrm{Rul}-\mathrm{Cl}$ & $2.181(4)$ \\
\hline $\mathrm{Rul}-\mathrm{C} 2$ & $2.164(4)$ & $\mathrm{Ru} 1-\mathrm{C} 2$ & $2.149(5)$ \\
\hline $\mathrm{Rul}-\mathrm{C} 3$ & $2.174(3)$ & $\mathrm{Rul}-\mathrm{C} 3$ & $2.157(5)$ \\
\hline $\mathrm{Rul}-\mathrm{C} 4$ & $2.150(3)$ & $\mathrm{Ru} 1-\mathrm{C} 4$ & $2.164(5)$ \\
\hline $\mathrm{Rul}-\mathrm{C} 5$ & $2.177(3)$ & $\mathrm{Ru} 1-\mathrm{C} 5$ & $2.194(5)$ \\
\hline $\mathrm{Rul}-\mathrm{C} 6$ & $2.185(3)$ & $\mathrm{Rul}-\mathrm{C} 6$ & $2.169(4)$ \\
\hline Arene $^{a)}-\mathrm{Rul}$ & $1.643(3)$ & Arene ${ }^{\mathrm{a})}-\mathrm{Rul}$ & $1.640(3)$ \\
\hline $\mathrm{C} 1-\mathrm{C} 2$ & $1.417(5)$ & $C(1)-C(2)$ & $1.419(7)$ \\
\hline $\mathrm{C} 2 \cdots \mathrm{C} 3$ & $1.416(6)$ & $C(2)-C(3)$ & $1.422(7)$ \\
\hline $\mathrm{C} 3-\mathrm{C} 4$ & $1.415(5$ & $C(3)-C(4)$ & $1.400(8)$ \\
\hline $\mathrm{C} 4-\mathrm{C} 5$ & $1.426(5)$ & $C(4)-C(5)$ & $1.422(7)$ \\
\hline $\mathrm{C} 5-\mathrm{C} 6$ & $1.419(5)$ & $C(5)-C(6)$ & $1.433(7)$ \\
\hline $\mathrm{Cl}-\mathrm{C} 6$ & $1.423(5)$ & $C(1)-C(6)$ & $1.422(7)$ \\
\hline $\mathrm{C} 6-\mathrm{C} 7$ & $1.504(5)$ & $C(6)-C(7)$ & $1.508(7)$ \\
\hline $\mathrm{C} 7-\mathrm{C} 8$ & $1.533(5)$ & $C(7)-C(8)$ & $1.526(7)$ \\
\hline $\mathrm{C} 8-\mathrm{C} 91 / \mathrm{C} 8-\mathrm{C} 92$ & $1.526(9) / 1.564(8)$ & $C(8)-C(9)$ & $1.496(7)$ \\
\hline $\mathrm{C} 91-\mathrm{O} 91$ / C92-O92 & $1.422(10) / 1.436(10)$ & $\mathrm{C}(9)-\mathrm{O}(1)$ & $1.448(6)$ \\
\hline $\mathrm{O} 91-\mathrm{C} 10 / \mathrm{O} 92-\mathrm{Cl} 0$ & $1.543(8) / 1.467(7)$ & & \\
\hline $\mathrm{Cl1}-\mathrm{Ru} 1-\mathrm{Cl} 2$ & $85.65(3)$ & $\mathrm{Cl}(1)-\mathrm{Ru}(1)-\mathrm{Cl}(2)$ & $87.28(4)$ \\
\hline $\mathrm{Cll}-\mathrm{Rul}-\mathrm{CllA}$ & $82.60(3)$ & $\mathrm{O}(1)-\mathrm{Ru}(1)-\mathrm{Cl}(1)$ & $83.57(10)$ \\
\hline $\mathrm{Cl} 2-\mathrm{Ru} 1-\mathrm{CllA}$ & $87.35(3)$ & $\mathrm{O}(1)-\mathrm{Ru}(1)-\mathrm{Cl}(2)$ & $82.37(10)$ \\
\hline Arene $^{a)}-\mathrm{Ru}-\mathrm{Cll}$ & $128.7(3)$ & Arene $-\mathrm{Ru}(1)-\mathrm{Cl}(1)$ & $129.3(1)$ \\
\hline Arene $^{\mathrm{a})}-\mathrm{Ru} 1-\mathrm{Cl} 2$ & $130.3(3)$ & Arene $-\mathrm{Ru}(1)-\mathrm{Cl}(2)$ & $128.2(1)$ \\
\hline Arene $^{(1)}-\mathrm{Ru}-\mathrm{Cll} \mathrm{A}$ & $126.6(3)$ & Arene $-\mathrm{Ru}-\mathrm{O}(1)$ & $129.9(1)$ \\
\hline
\end{tabular}

Arene $^{i t}=$ midpoint of the arene ring

taining to the data collection and structure solution are collected in Table 1. Table 2 provides important bond lengths and angles. The ether substituted complex crystallizes as a dimer, a structure which is commonly observed for complexes of the general composition $\left(\eta^{6}\right.$-arene $) \mathrm{RuCl}_{2}$. Two chloride bridges tie the ruthenium atoms together forming a central $\mathrm{Ru}_{2} \mathrm{Cl}_{2}$ rhombus. There is a centre of inversion located at the midpoint of the central $\mathrm{Ru}_{2} \mathrm{Cl}_{2}$ entity and the unit cell contains two half molecules of $2 \mathbf{a}$. As it is borne out by crystallographic symmetry, the coordinated arenes are situated on opposite sides of the central $\mathrm{Ru}_{2} \mathrm{Cl}_{2}$ ring to give the sterically preferred transoid arrangement. The methoxypropyl side chains point away from the terminal chloride ligands and the central $\mathrm{Ru}_{2} \mathrm{Cl}_{2}$ ring such that the molecule displays a "stretched" conformation. There is some disorder concerning atoms $\mathrm{C} 9$ and $\mathrm{O} 9$ of the methoxypropyl side chains. As is indicated in Figure 1, these atoms are disordered over two positions (C91, C92, O91, O92) with occupancy factors of 0.47 and 0.53 with the $\mathrm{C} 7$ and $\mathrm{C} 10$ atoms common to both different orientations. The bonds to the bridging chloride ligands are somewhat longer (2.443(1) and 2.448(1) $\AA$ ) than those to the terminal one (2.406(1) $\AA$ ), as it is usually observed for such dichloro bridged dimers. These values compare favourably with those for $\left[\left(\eta^{6}-\mathrm{C}_{6} \mathrm{Me}_{6}\right) \mathrm{RuCl}_{2}\right]_{2}(\mathrm{Ru}-\mathrm{Cl}($ terminal $)=2.394(1)$, $\mathrm{Ru}-\mathrm{Cl}$ (bridge $)=2.460(1) \AA$ ) [23] and the two independent molecules within the unit cell of $\left[(p \text {-cymene }) \mathrm{RuCl}_{2}\right]_{2}$ $(\mathrm{Ru}-\mathrm{Cl}($ terminal $)=2.416(3) \AA, \mathrm{Ru}-\mathrm{Cl}($ bridge $)=2.451(3)$ and 2.464(3) $\AA$ for the one and $\mathrm{Ru}-\mathrm{Cl}($ terminal $)=2.420$ and 2.435(3) $\AA, \mathrm{Ru}-\mathrm{Cl}($ bridge $)=2.437(3)-2.488(3) \AA$ for the other molecule) [24]. The $\mathrm{Ru}-\mathrm{Cl} 2$ bond is roughly orthogonal to the central $\mathrm{Ru}_{2} \mathrm{Cl}_{2}$ plane $\left(85.2^{\circ}\right)$ while the planes of the arene rings are tilted at an angle of $54.6^{\circ}$ against the $\mathrm{Ru}_{2} \mathrm{Cl}_{2}$ entity. All other bond parameters, including the average $\mathrm{Ru}-\mathrm{C}($ arene) distances, are unremarkable and warrant no further discussion.

The hydroxypropyl derivative 1a, on the other hand, crystallizes as a monomer. Intramolecular chelation makes the arene ligand an eight electron donor ligand and renders the ruthenium atom an electronically saturated 18 valence electron centre. The Ru-C6-C7-C8-C9-O1 six membered chelate adopts a half-chair conformation with the flap pointing toward Cll and is devoid of any notable strain. Thus, the $\mathrm{Ru}-\mathrm{C}$ (arene) bond lengths fall in the same range as those observed in 2a and deviations of individual values from the average are no larger as in non-tethered $2 \mathrm{a}$. The $\mathrm{Ru}-\mathrm{Cl}$ distances of 2.409(1) and 2.421(1) $\AA$ compare well to those found for the plethora of neutral adducts of the type $\left[\left(\eta^{6}\right.\right.$-arene $\left.) \mathrm{RuCl}_{2} \mathrm{~L}\right]$ and phosphine tethered complexes like $\left[\left\{\eta^{6}-\mathrm{C}_{6} \mathrm{H}_{5}\left(\mathrm{CH}_{2}\right)_{3} \mathrm{PMe}_{2}\right\} \mathrm{RuCl}_{2}\right] \quad(2.405(2)$ to $2.421(2) \AA)$, $\left[\left\{\eta^{6}-\mathrm{C}_{6} \mathrm{H}_{2} \mathrm{Me}_{3}-2,4,6-\left(1-\mathrm{C}_{3} \mathrm{H}_{6} \mathrm{PPh}_{2}\right)\right\} \mathrm{RuCl}_{2}\right] \quad$ (2.4159(10) and $2.4425(10) \AA)$, or in $\left[\left(\eta^{6}-\mathrm{C}_{6} \mathrm{Me}_{5} \mathrm{C}_{3} \mathrm{H}_{6} \mathrm{PPh}_{2}\right) \mathrm{RuCl}_{2}\right]$

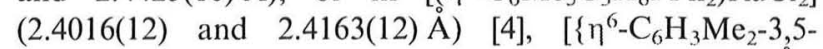
$\left.\left.\left(1-\mathrm{C}_{3} \mathrm{H}_{6} \mathrm{PPh}_{2}\right)\right\} \mathrm{RuCl}_{2}\right] \quad(2.397(2)$ and $2.420(2) \AA)$, $\left[\left\{\eta^{6}-\mathrm{C}_{6} \mathrm{H}_{4} \mathrm{Et}-4-\left(1-\mathrm{C}_{3} \mathrm{H}_{6} \mathrm{PPh}_{2}\right)\right\} \mathrm{RuCl}_{2}\right] \quad(2.4040(10)$ and $2.4073(11) \AA)[3]$, or $\left[\left\{\eta^{6}-\mathrm{C}_{6} \mathrm{H}_{5}\left(\mathrm{CHMeC}_{2} \mathrm{H}_{4}\right)_{3} \mathrm{PPh}_{2}\right\} \mathrm{RuCl}_{2}\right]$ (2.4037(7) and 2.4271(6) $\AA$ [9]. The $\mathrm{Ru}-\mathrm{O}$ bond length of 2.153(3) $\AA$ is very similar to that observed in the dicationic chelate $\left[\left\{\eta^{6}: \eta^{1}-\mathrm{C}_{6} \mathrm{H}_{5}\left(\mathrm{CH}_{2}\right)_{3} \mathrm{OH}\right\} \mathrm{Ru}(\text { phen })\right]^{2+}\left(\mathrm{BF}_{4}\right)_{2}{ }^{--}$where 
phen denotes 1,10-phenanthroline $(2.145(3) \AA$ ), but is notably longer as the $\mathrm{Ru}-\mathrm{O}$ (alkoxylate) bond in $\left[\left\{\eta^{6}: \eta^{1}-\mathrm{C}_{6} \mathrm{H}_{5}\left(\mathrm{CH}_{2}\right)_{3} \mathrm{O}\right\} \mathrm{Ru}(\text { bipy })\right]^{+}\left(\mathrm{BF}_{4}\right)^{--}$(bipy $=2,2^{\prime}$-bipyridine, 2.050(5) $\AA$ ) [14]. The $\mathrm{OH}$ proton, like every other hydrogen atom of this structure, was directly located from the electron density map. It is found to point away from the metal and to project toward a chloride ligand of a neighbour molecule forming a grossly linear $\left(154.9(1)^{\circ}\right) \mathrm{OH} \cdots \mathrm{Cl}$ bridge with a $\mathrm{H} \cdots \mathrm{Cl}$ separation of $2.24(1) \AA$ and an $\mathrm{O} \cdots \mathrm{Cl}$ distance of 3.0513(2) $\AA$. The $\mathrm{OH} \cdots \mathrm{Cl}$ bridge present in 1a is thus significantly shorter than the average hydrogen bond between an $\mathrm{OH}$ donor and a metal atom bonded chloride ligand as the acceptor $\left(\mathrm{d}_{\mathrm{av}} \mathrm{Cl} \cdots \mathrm{H}=2.349(9) \AA\right.$, $\mathrm{d}_{\mathrm{av}} \mathrm{O} \cdots \mathrm{Cl}=3.272(8) \AA$ ) [25]. This signals, that the $\mathrm{OH} \cdots \mathrm{Cl}$ interaction in 1a is rather strong. A similar intramolecular $\mathrm{OH} \cdots \mathrm{Cl}$ contact with an $\mathrm{O} \cdots \mathrm{Cl}$ distance of 3.121(2) $\AA$ and an $\mathrm{OH}^{\cdots} \mathrm{Cl}$ angle of $159.2^{\circ}$ has just been reported by Štěpnička, Therrien and their co-workers for $\left[\left\{\eta^{6}-\mathrm{C}_{6} \mathrm{H}_{5}\left(\mathrm{CH}_{2}\right)_{3} \mathrm{OH}\right\} \mathrm{RuCl}_{2}\left(\mathrm{PPh}_{3}\right)\right]$, the triphenylphosphine adduct of 1a [16].

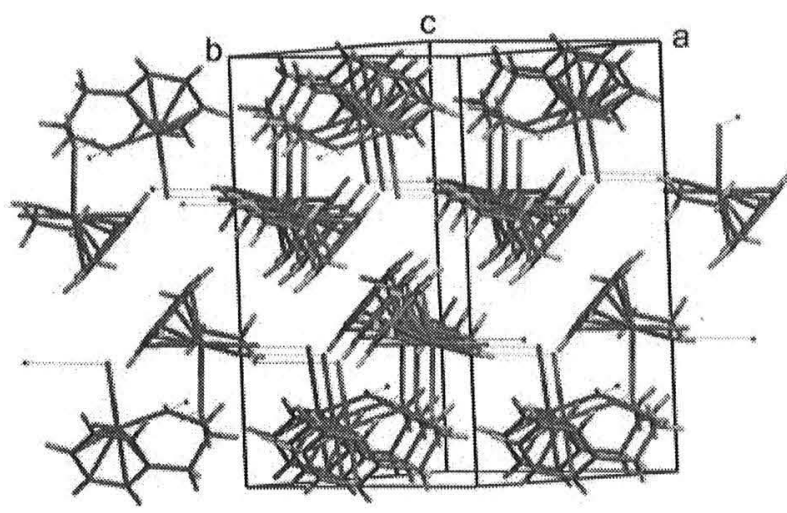

Figure 3 Plot showing the packing and the $\mathrm{OH}^{\cdots} \mathrm{Cl}$ contacts (dotted lines) within the solid state structure of compound 1a.

In 1a these interactions also form a peculiar hydrogen bonding network that determines the packing in the crystal. Molecules of 1a arrange in double sheets that run parallel to the crystallographic $a b$ plane. The $\mathrm{Ru}-\mathrm{Cl} 2$ vectors of the molecules belonging to the upper layer and those of the lower layer of each double sheet are roughly antiparallel to each others. Each molecule forms two $\mathrm{OH}^{\cdots} \mathrm{Cl}$ contacts with different neighbours from the other layer of the double sheet, one via its $\mathrm{OH}$ group and one via its $\mathrm{Cl} 2$ atom. As a whole, molecules interlinked by these hydrogen bonds form one-dimensional infinite zig-zag chains within the double sheets which propagate along the $a$ vector. The coordinated arene rings of the molecules building the one layer within a double sheet tilt toward the $\mathrm{Cl} 2$ atom of the constituents of the other. These $\mathrm{CH} \cdots \mathrm{Cl}$ contacts, however, exceed $3.8 \AA$ and are most probably too weak to allow for any significant interaction. Adjacent double sheets pack such that the arene rings are strictly parallel to each others. The distance between the arene planes of adjacent layers is $3.197 \AA$ and is thus shorter as the distance between the individual layers in graphite ( $3.35 \AA$ ). Still, in 1a the arene rings of molecules belonging to different sheets are offset against each others.

The structures of $\mathbf{1 a}$ and its triphenylphosphine adduct as well as the comparison to that of the corresponding methyl ether underpin the significance of even moderately strong hydrogen bridges in determining the molecular conformation as well as the association and packing of individual molecules and the physical properties (such as solubilities) of compounds.

\section{Phosphine adducts of 1a-3a}

Phosphine adducts of $\left[\left\{\eta^{6}-\mathrm{C}_{6} \mathrm{H}_{5}\left(\mathrm{CH}_{2}\right)_{n} \mathrm{OR}\right\} \mathrm{RuCl}_{2}\right]_{n}$ are readily prepared by reacting the corresponding dichloro complexes with a slight excess of a phosphine in $\mathrm{CH}_{2} \mathrm{Cl}_{2}$. In the case of $1 \mathrm{a}$ and $3 \mathrm{a}$ which are only moderately or nearly insoluble in this medium, gradual dissolution of the starting complex occurred as the phosphine complexes formed. The synthesis of the $\mathrm{P}\left(\mathrm{CH}_{2} \mathrm{OH}\right)_{3}$ derived complexes 1d,e requires the use of methanol as the solvent, and only intractable product mixtures were formed in $\mathrm{CH}_{2} \mathrm{Cl}_{2}$. Referring to the work of Therrien and Śtépnička [16], the decidedly higher solubility of the phosphine adducts may not only be due to the presence of solubilizing substituents on the phosphine but also to a change of the nature of the $\mathrm{OH} \cdots \mathrm{Cl}$ contacts from intermolecular to intramolecular ones. At present we have, however, no crystallographic evidence to support the presence of intramolecular $\mathrm{OH} \cdots \mathrm{Cl}$ interactions for the phosphine adducts reported herein.

All phosphine complexes are characterized by sharp singlet resonances in their ${ }^{31} \mathrm{P}$ NMR spectra with resonance shifts near $30 \mathrm{ppm}$ for the tricyclohexyl phosphine and the tris(hydroxymethyl)phosphine and of about $40 \mathrm{ppm}$ for the triisopropylphosphine derivatives. The proton and carbon13 NMR spectra likewise show the resonances of the ring protons and of the triisopropyl substituent (for $\mathbf{1 b}-\mathbf{3 b}$ ) in a symmetric environment, which indicates the presence of a molecular mirror plane. For the tricyclohexylphosphine complex $\mathbf{2 b}$ the appropriate number of $\mathrm{CH}_{2}$ multiplets appears in the ${ }^{1} \mathrm{H}$ and ${ }^{13} \mathrm{C}$ NMR spectra. Attempts to prepare the $\mathrm{P}\left(\mathrm{CH}_{2} \mathrm{OH}\right)_{3}$ derived monoadduct of the hydroxypropylbenzene derivative $1 \mathbf{d}$ initially lead to slightly impure samples with some admixture of another phosphine complex, as it was indicated by the presence of a second singlet resonance at somewhat lower field. This second symmetric phosphine complex was finally identified as the cationic bis(phosphine) adduct $\quad\left[\left\{\eta^{6}-\mathrm{C}_{6} \mathrm{H}_{5}\left(\mathrm{CH}_{2}\right)_{3} \mathrm{OH}\right\} \mathrm{RuCl}-\right.$ $\left.\left\{\mathrm{P}\left(\mathrm{CH}_{2} \mathrm{OH}\right)_{3}\right\}_{2}\right]^{+} \mathrm{Cl}-$. It was subsequently prepared and fully characterized by reacting $\left[\left\{\eta^{6}-\mathrm{C}_{6} \mathrm{H}_{5}\left(\mathrm{CH}_{2}\right)_{3} \mathrm{OH}\right\} \mathrm{RuCl}_{2}\right]$ and $\mathrm{P}\left(\mathrm{CH}_{2} \mathrm{OH}\right)_{3}$ in a stoichiometric ratio of $1: 2$. Mixtures of $\left[\left\{\eta^{6}-\mathrm{C}_{6} \mathrm{H}_{5}\left(\mathrm{CH}_{2}\right)_{3} \mathrm{OH}\right\} \mathrm{RuCl}\left\{\mathrm{P}\left(\mathrm{CH}_{2} \mathrm{OH}\right)_{3}\right\}_{2}\right]^{+} \mathrm{Cl}^{--}$and $\left[\left\{\eta^{6}-\mathrm{C}_{6} \mathrm{H}_{5}\left(\mathrm{CH}_{2}\right)_{3} \mathrm{OH}\right\} \mathrm{RuCl}_{2}\right]$ in $\mathrm{CD}_{2} \mathrm{Cl}_{2}$ are gradually transformed to give predominantly $\left[\left\{\eta^{6}-\mathrm{C}_{6} \mathrm{H}_{5}\left(\mathrm{CH}_{2}\right)_{3} \mathrm{OH}\right\}\right.$ $\left.\mathrm{RuCl}_{2}\left\{\mathrm{P}\left(\mathrm{CH}_{2} \mathrm{OH}\right)_{3}\right\}\right]$. Formation of the cationic bisadduct $\left[\left(\eta^{6} \text {-arene }\right) \mathrm{RuCl}\left\{\mathrm{P}\left(\mathrm{CH}_{2} \mathrm{OH}\right)_{3}\right\}_{2}\right]^{+} \quad \mathrm{Cl}^{-}$was even more pronounced in the case of $\mathbf{3 a}$, where its formation besides the expected monoadduct $\left[\left\{\eta^{6}-\mathrm{C}_{6} \mathrm{H}_{5}\left(\mathrm{CH}_{2}\right)_{2} \mathrm{OH}\right\} \mathrm{RuCl}_{2}-\right.$ 
$\left.\left\{\mathrm{P}\left(\mathrm{CH}_{2} \mathrm{OH}\right)_{3}\right\}\right]$ accounted to about $30 \%$ of phosphine containing species even when substoichiometric amounts of the phosphine were employed. Owing to the low solubility of $3 \mathrm{a}$ in $\mathrm{CH}_{2} \mathrm{Cl}_{2}$ and the formation of several side products, reactions of $3 \mathrm{a}$ with $\mathrm{P}\left(\mathrm{CH}_{2} \mathrm{OH}\right)_{3}$ had to be performed in methanol as the solvent. The highly polar methanol solvent considerably aids in dissociating a chloride ligand, thus opening a coordination site which is then occupied by a second equivalent of the phosphine. The outcome of the reactions with less than one equivalent of $\mathrm{P}\left(\mathrm{CH}_{2} \mathrm{OH}\right)_{3}$ indicates, that under these conditions chloride substitution occurs at a similar rate as adduct formation. Of note is the finding, that $\mathrm{P}\left(\mathrm{CH}_{2} \mathrm{OH}\right)_{3}$ here coordinates without any loss of formaldehyde from the phosphine. Reactions utilizing this phosphine sometimes provide complexes that contain partially deformylated $\mathrm{PH}_{\mathrm{n}}\left(\mathrm{CH}_{2} \mathrm{OH}\right)_{3-n}$ ligands, mostly with high chemoselectivity. A notable example in ruthenium chemistry is provided by the work of Whittlesey [26]. The factors that govern the event and the degree of deformylation from this phosphine are presently unknown. All the new complexes bearing the $\mathrm{P}\left(\mathrm{CH}_{2} \mathrm{OH}\right)_{3}$ ligand described herein are hygroscopic and readily dissolve in water. This may make them suitable precursors for water soluble arene monophosphine half-sandwich catalysts. Half sandwich ruthenium arene complexes have sucessfully been employed in numerous catalytical applications [27] such as atom transfer radical polymerization (ATRP) [28], ring-opening or ring-closing metathesis $[2,29-31]$, or the cycloisomerization of diolefins [15]. We also note that recent work disclosed the utility of closely related complexes $\left[\left(\eta^{6}\right.\right.$-arene $\left.) \mathrm{RuCl}_{2}\left\{\mathrm{P}\left(\mathrm{CH}_{2} \mathrm{OH}\right)_{3}\right\}\right]$ in the catalytic isomerization of allylic alcohols and the hydration of alkynes to ketones under biphasic conditions [32]. Attempts to crystallize any of these complexes in order to assess the intra- and intermolecular hydrogen bonding which may involve the hydroxyalkyl side chains on the arene and the phosphine hydroxymethyl groups [26] have not yet provided suitable specimen for X-ray diffraction studies.

\section{Electrochemistry}

The electrochemical behaviour of half-sandwich dichloro complexes of the type $\left[\left(\eta^{6} \text {-arene }\right) \mathrm{RuCl}_{2}\right]_{2}$ has been probed by various authors and displays a rather intricate behaviour with a rich chemistry following or even preceding each electron transfer step. As it is evidenced by these investigations, prototypical $\left[(\mathrm{p} \text {-cymene }) \mathrm{RuCl}_{2}\right]_{2}$, in supporting electrolyte solution, is in equilibrium with the salt $\left[\{(\mathrm{p} \text {-cymene }) \mathrm{Ru}\}_{2}\left(\mu-\mathrm{Cl}_{3}\right)\right]^{+} \mathrm{Cl}^{-}$. This dissociation step is promoted by media of high ionic strength and is virtually complete in $\mathrm{CH}_{2} \mathrm{Cl}_{2} / \mathrm{NBu}_{4} \mathrm{PF}_{6}$. The trichloro bridged dimer gives a cathodic peak which precedes the reduction of the neutral dichloro bridged dimer. Authentic $\left[\left(\eta^{6} \text {-arene }\right) \mathrm{RuCl}_{2}\right]_{2}$ is reduced in a chemically partially reversible and kinetically quasireversible one-electron step, and the resulting reduction product was assigned the unsymmetrical dichloro bridged structure $[\{(\mathrm{p}$-cymene $) \mathrm{Ru}\}$ -
$(\mu-\mathrm{Cl})_{2}\{\mathrm{RuCl}(\mathrm{p} \text {-cymene })]^{\cdots}$. This latter species dissociates another equivalent of chloride but may be back oxidized to the starting dimer by a sequence involving electron transfer and chloride association steps [32]. Anodic oxidation of $\left[\left(\eta^{6}-\mathrm{C}_{6} \mathrm{Me}_{6}\right) \mathrm{RuCl}_{2}\right]_{2}$ was observed to proceed in two sequential one-electron steps. Both processes are prone to fast chemical follow processes which ultimately yield $\left[\left(\eta^{6}-\mathrm{C}_{6} \mathrm{Me}_{6}\right) \mathrm{RuCl}_{3}\right]$ and oligomeric $\left[\left(\eta^{6}-\mathrm{C}_{6} \mathrm{Me}_{6}\right) \mathrm{RuCl}\right]_{\mathrm{n}} \mathrm{n}+$ by disproportionation [33].

Here, we report on the electrochemical properties of $\left.\left[\left\{\eta^{6}-\mathrm{C}_{6} \mathrm{H}_{5}\left(\mathrm{CH}_{2}\right)_{3} \mathrm{OMe}\right)\right\} \mathrm{RuCl}_{2}\right]_{2}$ (2a) in $\mathrm{CH}_{2} \mathrm{Cl}_{2} / \mathrm{NBu}_{4} \mathrm{PF}_{6}$. Voltammograms at room temperature show a close to reversible reduction at $-0.79 \mathrm{~V}$ (peaks $\mathrm{A} / \mathrm{A}^{\prime}$ ) and an irre-

a)

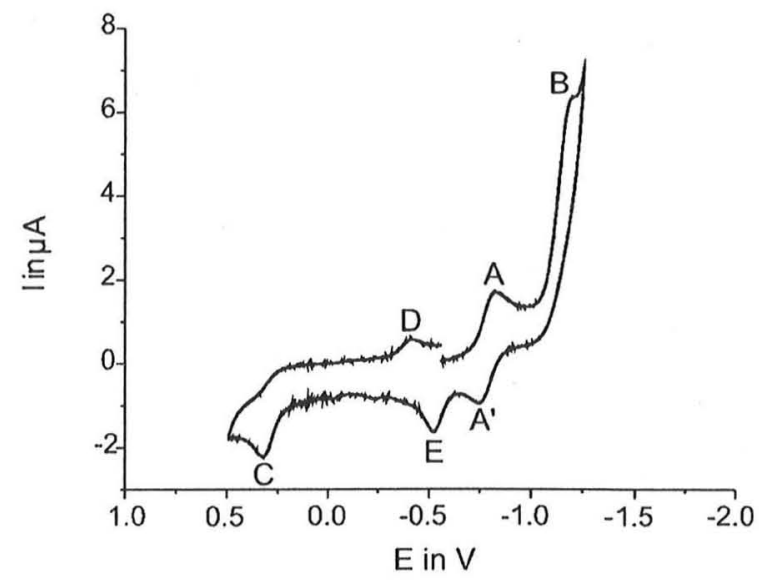

b)

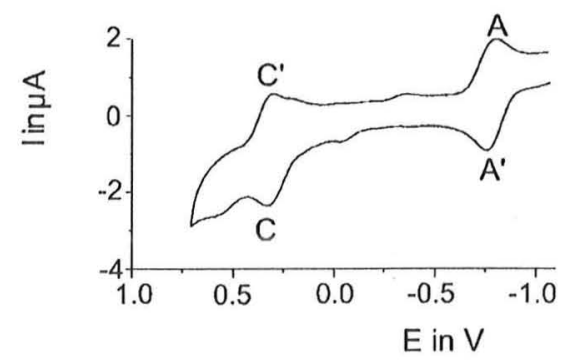

c)

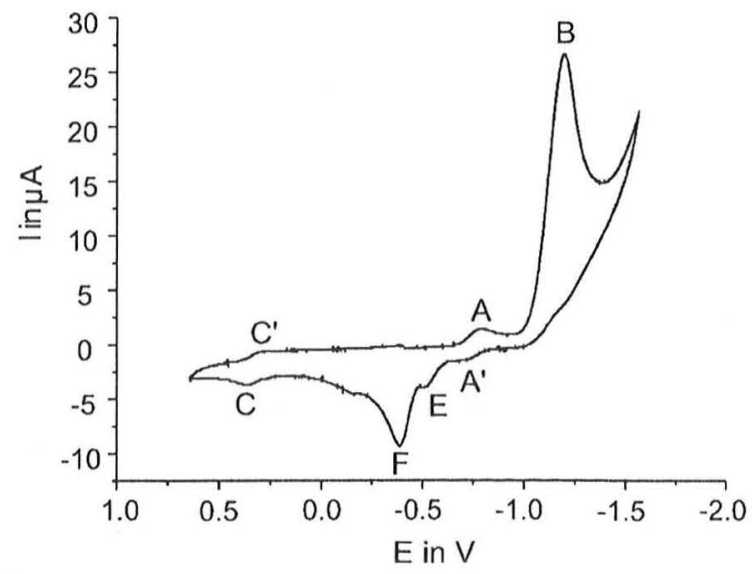

Figure 4 Cyclic voltammograms of complex $2 \mathbf{a}$ in $\mathrm{CH}_{2} \mathrm{Cl}_{2} /$ $\mathrm{NBu}_{4} \mathrm{PF}_{6}$ at $\mathrm{v}=0.1 \mathrm{~V} / \mathrm{s}$. a) $298 \mathrm{~K}$; b) $196 \mathrm{~K}\left(\mathrm{CO}_{2} /\right.$ isopropanol slush bath); c) $298 \mathrm{~K}$, but in the presence of excess $\mathrm{NaSbF}_{6}$. 
versible anodic oxidation at $E_{p}=0.33 \mathrm{~V}$ (peak C). Peaks A and $C$ are associated with about the same peak currents under all conditions (Figures 4a-c). When the scan is reversed after traversing peak $C$, the new cathodic peak $D$ is observed at $E_{p}=-0.42 \mathrm{~V}$. As the sweep rate is increased or the temperature is lowered, the reversibility of the oxidation step increases and the associated counter peak $\mathrm{C}^{\prime}$ appears $\left(E_{1 / 2}=0.285 \mathrm{~V}\right)$ with the concomitant disappearance of peak D (see Figure 4b). This behaviour is highly reminiscent of other dichloro bridged ruthenium dimers such that peaks $\mathrm{A}$ and $\mathrm{C}$ are due to the reduction and the oxidation of $\left.\left[\left\{\eta^{6}-\mathrm{C}_{6} \mathrm{H}_{5}\left(\mathrm{CH}_{2}\right)_{3} \mathrm{OMe}\right)\right\} \mathrm{RuCl}_{2}\right]_{2}$. In the case of $\left[\left(\eta^{6}-\mathrm{C}_{6} \mathrm{Me}_{6}\right) \mathrm{RuCl}_{2}\right]_{2}$, a peak corresponding to $\mathrm{D}$ has been ascribed to the reduction of monomeric $\left[\left(\eta^{6}-\mathrm{C}_{6} \mathrm{Me}_{6}\right) \mathrm{RuCl}_{3}\right]$ formed in the disproportionation following oxidation. Compared to $\left[\left(\eta^{6}-\mathrm{C}_{6} \mathrm{Me}_{6}\right) \mathrm{RuCl}_{2}\right]_{2}$, wave $\mathrm{C} / \mathrm{C}^{\prime}$ is shifted by about $450 \mathrm{mV}$ to more negative potentials and this may indicate some remarkable stabilization of the oxidized form through intramolecular solvation by the appended ether moiety. When the cathodic sweep is continued past the $\mathrm{A} / \mathrm{A}^{\prime}$ couple, another irreversible reduction peak is observed at ca. $-1.20 \mathrm{~V}$ (peak $B$ in figures $4 a, c)$. This feature is associated with considerably higher currents as the $\mathrm{A} / \mathrm{A}^{\prime}$ couple and peak C. Peak B is followed by additional, broad and ill-defined features at even more cathodic potentials (not shown in Figures 4a-c). On the reverse scan, an additional anodic peak (peak E) at $-0.53 \mathrm{~V}$ indicates the formation of a new electroactive follow product.

Addition of the mild chloride scavenger $\mathrm{NaSbF}_{6}$ to the supporting electrolyte solution has the effect of further increasing the intensity of peak $B$ and decreasing the chemical reversibility of the $\mathrm{A} / \mathrm{A}^{\prime}$ couple, most probably by accelerating the rate of chloride dissociation from reduced $\left.\left.\left[\left\{\eta^{6}-\mathrm{C}_{6} \mathrm{H}_{5}\left(\mathrm{CH}_{2}\right)_{3} \mathrm{OMe}\right)\right\} \mathrm{RuCl}_{2}\right]_{2}\right]^{\cdots}$ (Figure 4c). Given the known propensity of $\left[\left(\eta^{6} \text {-arene }\right) \mathrm{RuCl}_{2}\right]_{2}$ to chloride loss in ionizing media and the qualitative changes induced by the presence of $\mathrm{NaSbF}_{6}$, we assign peak $\mathrm{B}$ as the reduction of such a chloride dissociation product. Possible candidates are trichloro bridged $\left[\left\{\eta^{6}-\mathrm{C}_{6} \mathrm{H}_{5}\left(\mathrm{CH}_{2}\right)_{3} \mathrm{OMe}\right\} \mathrm{Ru}\left(\mu-\mathrm{Cl}_{3}\right) \mathrm{Ru}\right.$ $\left.\left\{\eta^{6}-\mathrm{C}_{6} \mathrm{H}_{5}\left(\mathrm{CH}_{2}\right)_{3} \mathrm{OMe}\right\}\right]^{+}$or an unsymmetric complex $\left[\left\{\eta^{6}: \eta^{1}-\mathrm{C}_{6} \mathrm{H}_{5}\left(\mathrm{CH}_{2}\right)_{3} \mathrm{OMe}\right\} \mathrm{Ru}\left(\mu-\mathrm{Cl}_{2}\right) \mathrm{RuCl}\left\{\eta^{6}-\mathrm{C}_{6} \mathrm{H}_{5}\left(\mathrm{CH}_{2}\right)_{3}-\right.\right.$ $\mathrm{OMe}\}]$ with one appended ether moiety coordinated to a ruthenium centre. While additional experiments are necessary to unambiguously establish the nature of this species, we favour the latter structure since trichloro bridged dimers are commonly easier reduced as their neutral dichloro bridged precursors. The hydroxy appended complexes gave only ill defined, broad voltammetric responses and were not further investigated. This is possibly due to a combination of their limited solubility and a coupling of proton transfer from the side chain hydroxy group to the electron transfer processes.

Half-sandwich phosphine complexes of the type $\left[\left(\eta^{6}\right.\right.$-arene $\left.) \mathrm{RuCl}_{2}\left(\mathrm{PR}_{3}\right)\right]$, on the other hand, display much simpler electrochemical responses and usually undergo a chemically reversible oxidation at fairly positive potentials $[4,16,34]$. This oxidation is assigned as the $\mathrm{Ru}(\mathrm{II} / \mathrm{III})$ couple, i. e. as an essentially metal centred process. The

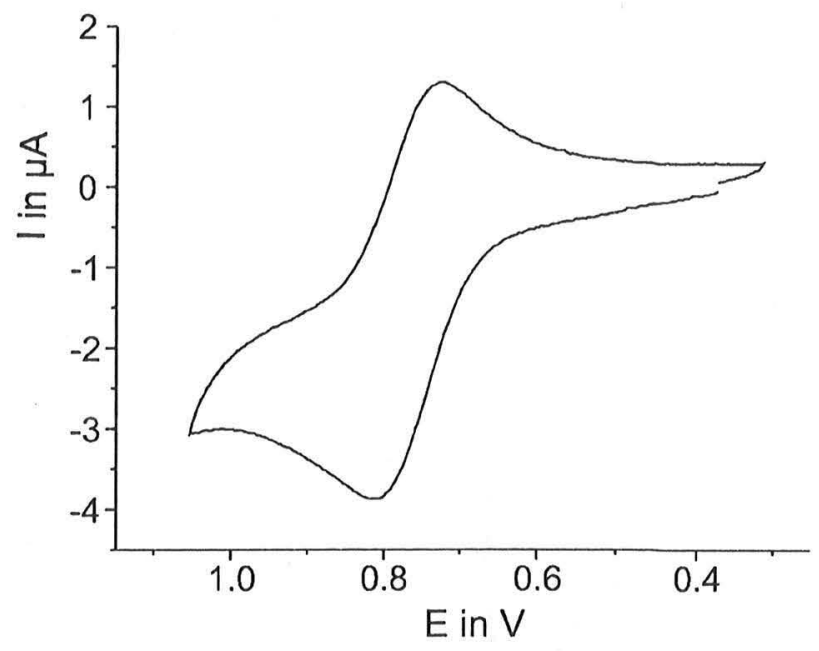

Figure $5 \mathrm{CV}$ of compound $2 \mathrm{~b}$ in $\mathrm{CH}_{2} \mathrm{Cl}_{2} / \mathrm{NBu}_{4} \mathrm{PF}_{6}, 298 \mathrm{~K}, \mathrm{v}=0.1 \mathrm{~V} / \mathrm{s}$.

half-wave potentials thus reflect the electron density at the ruthenium atom and electron donation from the ancillary ligands. We observe essentially the same behaviour for the phosphine adducts $\mathbf{1 b - d ,} \mathbf{2} \mathbf{b}, \mathbf{c}$ and $\mathbf{3 b}$. There is just one anodic wave within the $\mathrm{CH}_{2} \mathrm{Cl}_{2} / \mathrm{NBu}_{4} \mathrm{PF}_{6}$ electrolyte window, and this wave always constitutes a chemically reversible couple with $\mathrm{i}_{\mathrm{p}, \mathrm{c}} / \mathrm{i}_{\mathrm{p}, \mathrm{a}}$ ratios of at least 0.95 even at low sweep rates. The voltammetric response of compound $\mathbf{2 b}$ is displayed as Figure 5 and may serve as a representative example. Peak potential differences slightly exceed the values of the internal ferrocene/ferrocenium standard with larger differences as the sweep rate is increased. Such findings are diagnostic of somewhat sluggish electron transfer kinetics (quasireversible behaviour). Half-wave potentials and peakto-peak separations are listed in Table 3. Comparison of the data shows that the half-wave potentials are sensitive to both, the identity of the phosphine and of the arene ligands. The more basic $\mathrm{P}^{\mathrm{i}} \mathrm{Pr}_{3}$ and $\mathrm{PCy}_{3}$ adducts lead to distinctly lower $\mathrm{E}_{1 / 2}$ values as the tris(hydroxylated) $\mathrm{P}\left(\mathrm{CH}_{2} \mathrm{OH}\right)_{3}$ with a difference of $190 \mathrm{mV}$ between $\mathbf{1 b}$ and $\mathbf{1 d}$. No clear trend arises from the substitution of the arene ligand. While the 3-hydroxypropylbenzene derived complex $\mathbf{1 b}$ is somewhat easier to oxidize than its methyl ether $2 \mathbf{b}$, the opposite holds for the $\mathrm{PCy}_{3}$ complexes 1c, 2c.

Table 3 Redox potentials of the complexes; peak-to-peak separations are given in parantheses ${ }^{\text {a) }}$

\begin{tabular}{|c|c|}
\hline 2a & $\begin{array}{l}+0.295(60)\left(C / C^{\prime}\right)^{b},-0.790(65)\left(A^{b} / A^{\prime}\right) ;-1.20(B)^{c)},-0.53(E)^{d)}, \\
-0.43(F)^{c},-0.42(D)^{f}\end{array}$ \\
\hline 1b & $+0.705(82)$ \\
\hline 1c & $+0.735(81)$ \\
\hline $1 d$ & $+0.895(81)$ \\
\hline 2b & $+0.770(73)$ \\
\hline $2 \mathrm{c}$ & $+0.685(75)$ \\
\hline $3 b$ & $+0.775(77)$ \\
\hline
\end{tabular}

a) potentials are provided relative to the $\mathrm{Fc} / \mathrm{Fc}^{+}$scale; b) at $196 \mathrm{~K}$; ${ }^{\mathrm{c})}$ irreversible reduction peak; ${ }^{\text {d) }}$ irreversible anodic peak following reduction; ${ }^{\mathrm{c})}$ irreversible anodic peak following reduction in the presence of $\mathrm{NaSbF}_{6} ;{ }^{n}$ irreversible cathodic peak following oxidation. 


\section{Experimental Section}

Materials and methods. Hydrated $\mathrm{RuCl}_{3}(\mathrm{Ru}$ content $42.41 \%)$ was obtained from Johnsson Matthey, and $\mathrm{P}^{\prime} \mathrm{Pr}_{3}, \mathrm{PCy}_{3}$, and $\mathrm{P}\left(\mathrm{CH}_{2} \mathrm{OH}\right)_{3}$ from Strem. Solvents were dried over the appropriate drying agents, distilled and stored under argon over molecular sieves. The functionalized cyclohexadienes required for the synthesis of the $\left[\left(\eta^{6} \text {-arene }\right) \mathrm{RuCl}_{2}\right]_{n}$ complexes were prepared by Birch reduction of their aromatic precursors following the general protocol [19]. Electrochemistry was performed in a home-built cylindrical vacuum tight one compartment cell. A spiral shaped $\mathrm{Pt}$ wire and a $\mathrm{Ag}$ wire as the counter and reference electrodes are sealed into opposite sides of the glass wall while the respective working electrode (Pt or glassy carbon $1.1 \mathrm{~mm}$ polished with $0.25 \mu \mathrm{m}$ diamond paste (Buehler-Wirtz) before each experiment) is introduced via a teflon screw cap with a suitable fitting. The cell may be attached to a conventional Schlenk line via two sidearms equipped with teflon screw valves and allows experiments to be performed under an atmosphere of argon with approximately $2.5 \mathrm{ml}$ of analyte solution. $\mathrm{CH}_{2} \mathrm{Cl}_{2}$ for electrochemical work was obtained from Fluka (Burdick\&Jackson Brand) and freshly distilled from $\mathrm{CaH}_{2}$ before use. $\mathrm{NBu}_{4} \mathrm{PF}_{6}(0.25 \mathrm{mM})$ was used as the supporting electrolyte. All potentials are referenced versus the ferrocene/ferrocenium couple. Electrochemical data were acquired with a computer controlled EG\&G model 273 potentiostat utilizing the EG\&G 250 software package. NMR spectra were recorded on either a Bruker AC 250 or a Bruker AS 200 series spectrometer, at $293 \mathrm{~K}$, in the indicated solvent. Resonance shifts were referenced to residual, partially protonated solvent $\left({ }^{1} \mathrm{H}\right)$, the solvent signal itself $\left({ }^{13} \mathrm{C}\right)$ or external $\mathrm{H}_{3} \mathrm{PO}_{4}\left({ }^{31} \mathrm{P}\right)$.

$\left\{\left.\left\{\eta^{6}-\mathbf{C}_{6} \mathbf{H}_{5}\left(\mathrm{CH}_{2}\right)_{3} \mathrm{OH}\right\} \mathrm{RuCl}_{2}\right|_{2}\right.$ (1a): In a typical run, $9.30 \mathrm{~g}$ (67.30 mmol) of (1,4-cyclohexadienyl)-1-propanol was combined with $2.78 \mathrm{~g}(11.66 \mathrm{mmol})$ of hydrated $\mathrm{RuCl}_{3}$ in $70 \mathrm{ml}$ of ethanol. The mixture was heated under reflux for $6 \mathrm{~h}$. The microcrystalline solid obtained after storing the mother liquor in the fridge overnight was recrystallized from hot ethanol to give orange crystals of $1 \mathrm{a}$ in a yield of $2.79 \mathrm{~g}(77.6 \%)$. Analysis calcd. for $\mathrm{C}_{9} \mathrm{H}_{12} \mathrm{Cl}_{2} \mathrm{ORu}$ (308.2); C 35.43 (calc 35.08); H 3.97 (3.93) \%;. $\mathrm{m}_{\mathrm{p}}=230.5^{\circ} \mathrm{C}$.

' $\mathrm{H}-\mathrm{NMR}\left(\mathrm{CDCl}_{3}\right): \delta=1.85\left(\mathrm{tt}, J=7.2,7.0 \mathrm{~Hz}, 2 \mathrm{H}, \mathrm{CH}_{2} \mathrm{CH}_{2} \mathrm{CH}_{2}\right), 2.63(\mathrm{t}$, $\left.J=7.2 \mathrm{~Hz}, 2 \mathrm{H}, \mathrm{PhCH}_{2}\right), 3.38\left(\mathrm{t}, J=7.0 \mathrm{~Hz}, 2 \mathrm{H}, \mathrm{CH}_{2} \mathrm{O}\right), 5.39(\mathrm{~d}, J=$ $5.4 \mathrm{~Hz}, 2 \mathrm{H}), 5.57(\mathrm{t}, J=5.1 \mathrm{~Hz}, 2 \mathrm{H}), 5.64(\mathrm{dt}, J=5.4,5.1 \mathrm{~Hz}, 1 \mathrm{H}) .{ }^{1} \mathrm{H}-$ NMR (dmso-d $\left.\mathrm{d}_{6}\right): \delta=1.81\left(\mathrm{tt}, J=7.6,6.3 \mathrm{~Hz}, 2 \mathrm{H}, \mathrm{CH}_{2} \mathrm{CH}_{2} \mathrm{CH}_{2}\right), 2.43(\mathrm{t}$ $\left.J=7.6 \mathrm{~Hz}, 2 \mathrm{H}, \mathrm{PhCH}_{2}\right), 3.36\left(\mathrm{t}, J=6.3 \mathrm{~Hz}, 2 \mathrm{H}, \mathrm{CH}_{2} \mathrm{O}\right), 5.73(\mathrm{t}, J=$ $5.5 \mathrm{~Hz}, 1 \mathrm{H}), 5.74(\mathrm{~d}, J=5.5 \mathrm{~Hz}, 2 \mathrm{H}), 5.98(\mathrm{t}, J=5.5 \mathrm{~Hz}, 2 \mathrm{H}) .{ }^{13} \mathrm{C}$ $\operatorname{NMR}\left(\mathrm{CDCl}_{3}\right): \delta=29.76\left(\mathrm{~s}, \mathrm{CH}_{2}\right), 30.05\left(\mathrm{~s}, \mathrm{PhCH}_{2}\right), 71.79\left(\mathrm{~s}, \mathrm{CH}_{2} \mathrm{O}\right), 80.17$, $80.86,84.37$ (each s, $\mathrm{CH}), 111.89\left(\mathrm{C}_{\mathrm{q}}\right)$.

$\left.\left[\left\{\eta^{6}-\mathrm{C}_{6} \mathbf{H}_{5}\left(\mathrm{CH}_{2}\right)_{3} \mathbf{O H}\right)\right\} \mathbf{R u}\left(\mathrm{P}^{i} \mathbf{P r}_{3}\right) \mathrm{Cl}_{2}\right]$ (1b): $0.30 \mathrm{~g}(0.97 \mathrm{mmol})$ of 1a was reacted with $185 \mu \mathrm{l}(0.48 \mathrm{mmol})$ of $\mathrm{P}^{\prime} \mathrm{Pr}_{3}$ in $5 \mathrm{ml}$ of $\mathrm{CH}_{2} \mathrm{Cl}_{2}$. The reaction mixture was stirred overnight and filtered by cannula. The clear solution was dried in vacuo. Then the residue was washed with $3 \times 4 \mathrm{ml}$ of $\mathrm{Et}_{2} \mathrm{O}$. Drying in vacuo gave $354 \mathrm{mg}$ of $\mathbf{1 b}(77.7 \%)$. Analysis calcd. for $\mathrm{C}_{18} \mathrm{H}_{33} \mathrm{Cl}_{2} \mathrm{OPRu}$ (468.4); $\mathrm{C} 47.10$ (calc 46.16); H $7.46(7.10) \% . m_{p}=115.0{ }^{\circ} \mathrm{C}$.

${ }^{1} \mathrm{H}-\mathrm{NMR}\left(\mathrm{CDCl}_{3}\right): \delta=1.28,1.34$ (each d, $J=7.2 \mathrm{~Hz}, 9 \mathrm{H}, \mathrm{CH}_{3}\left(\mathrm{P}^{\prime} \operatorname{Pr}_{3}\right)$ ) $1.92\left(\mathrm{tt}, J=8.55,6.2 \mathrm{~Hz}, 2 \mathrm{H}, \mathrm{CH}_{2} \mathrm{CH}_{2} \mathrm{CH}_{2}\right), 2.71(\mathrm{t}, J=8.55 \mathrm{~Hz}, 2 \mathrm{H}$, $\left.\mathrm{PhCH}_{2}\right), 2.77\left(\mathrm{~m}, 3 \mathrm{H}, \mathrm{CH}\left(\mathrm{P}^{\mathrm{i}} \mathrm{Pr}_{3}\right)\right), 3.43\left(\mathrm{t}, J=6.2 \mathrm{~Hz}, 2 \mathrm{H}, \mathrm{OCH}_{2}\right), 5.31(\mathrm{t}$, $J=5.6 \mathrm{~Hz}, 2 \mathrm{H}), 5.42(\mathrm{~d}, J=5.8 \mathrm{~Hz}, 2 \mathrm{H}), 5.57(\mathrm{dt}, J=5.8,5.6 \mathrm{~Hz}, 1 \mathrm{H})$. ${ }^{13} \mathrm{C} \mathrm{NMR}\left(\mathrm{CDCl}_{3}\right): \delta=19.84\left(\mathrm{~s}, \mathrm{CH}_{3}\right) 25.58\left(\mathrm{~d}, \mathrm{~J}_{\mathrm{P}-\mathrm{C}}=20.43 \mathrm{~Hz}, \mathrm{CH}\right), 29.12$ $\left(\mathrm{s}, \mathrm{CCH}_{2}\right), 29.72\left(\mathrm{~s}, \mathrm{PhCH}_{2}\right), 71.72\left(\mathrm{~s}, \mathrm{CH}_{2} \mathrm{O}\right), 77.67,85.20($ each $\mathrm{s}, \mathrm{CH})$ $87.94\left(\mathrm{~d},{ }^{2} J_{\mathrm{P}-\mathrm{C}}=5.8 \mathrm{~Hz}, \mathrm{CH}\right), 111.89\left(\mathrm{~d}, \mathrm{C}_{\mathrm{q}},{ }^{2} J_{\mathrm{P}-\mathrm{C}}=7.2 \mathrm{~Hz}\right),{ }^{31} \mathrm{P}$ NMR $\left(\mathrm{CDCl}_{3}\right): \delta=36.52\left(\mathrm{~s}, \mathrm{P}^{\prime} \mathrm{Pr}_{3}\right)$;.
I $\left.\left.\left\{\mathrm{C}_{6} \mathrm{H}_{5}\left(\mathrm{CH}_{2}\right)_{3} \mathrm{OH}\right)\right\} \mathbf{R u}\left(\mathrm{PCy}_{3}\right) \mathrm{Cl}_{2}\right]$ (1c): Compound 1a $(0.30 \mathrm{~g}$, $0.97 \mathrm{mmol})$ and $0.273 \mathrm{~g}(0.49 \mathrm{mmol})$ of $\mathrm{PCy}_{3}$ were dissolved in $6 \mathrm{ml}$ of $\mathrm{CH}_{2} \mathrm{Cl}_{2}$ and stirred overnight. The filtered solution was dried in vacuo and the residue was washed with $3 \times 4 \mathrm{ml}$ of $\mathrm{Et}_{2} \mathrm{O}$ and dried. Compound 1a was obtained as an orange brown fluffy powder in a yield of $396 \mathrm{mg}(69.2 \%)$. Analysis calcd. for $\mathrm{C}_{27} \mathrm{H}_{45} \mathrm{Cl}_{2} \mathrm{OPRu}$ (588.6); C 56.00 (calc 55.16); H 8.25 (7.71) \%. $\mathrm{m}_{\mathrm{p}}=141.0^{\circ} \mathrm{C}$.

${ }^{1} \mathrm{H}-\mathrm{NMR}\left(\mathrm{CDCl}_{3}\right): \delta=1.14-1.55(\mathrm{~m}, \mathrm{br}, 16 \mathrm{H}), 1.6-1.9(\mathrm{~m}, 10 \mathrm{H}), 2.23(\mathrm{~m}$, $4 \mathrm{H}), 2.49(\mathrm{~m}, 3 \mathrm{H})$, all $\left.\mathrm{CH}_{2}, \mathrm{CH}\left(\mathrm{PCy}_{3}\right)\right), 1.93(\mathrm{tt}, J=7.7,6.2 \mathrm{~Hz}, 2 \mathrm{H}$, $\left.\mathrm{CH}_{2} \mathrm{CH}_{2} \mathrm{CH}_{2}\right), 2.71\left(\mathrm{t}, J=7.7 \mathrm{~Hz}, 2 \mathrm{H}, \mathrm{PhCH}_{2}\right), 3.46(\mathrm{t}, J=6.2 \mathrm{~Hz}, 2 \mathrm{H}$, $\left.\mathrm{CH}_{2} \mathrm{O}\right), 5.39(\mathrm{~m}, 3 \mathrm{H}), 5.52(\mathrm{t}, J=5.0 \mathrm{~Hz}, 2 \mathrm{H}) \cdot{ }^{13} \mathrm{C} \mathrm{NMR}\left(\mathrm{CDCl}_{3}\right): \delta=27.9$ 28.05, 29.36, 30.00, 30.26 (each s, $\left.\mathrm{CH}_{2}\right), 36.16\left(\mathrm{~d}, \mathrm{~J}_{\mathrm{PaC}}=18.9 \mathrm{~Hz}, \mathrm{CH}\left(\mathrm{PCy}_{3}\right)\right.$, $72.13\left(\mathrm{~s}, \mathrm{OCH}_{2}\right), 77.60,84.97(\mathrm{~s}, \mathrm{CH}), 88.75\left(\mathrm{~d},{ }^{2} J_{\mathrm{P}-\mathrm{C}}=5.1 \mathrm{~Hz}, \mathrm{CH}\right), 112.05$ $\left(\mathrm{d},{ }^{2} \mathrm{~J}_{\mathrm{P}-\mathrm{C}}=6.3 \mathrm{~Hz}, \mathrm{C}_{\mathrm{q}}\right) .{ }^{31} \mathrm{P}$ NMR $\left(\mathrm{CDCl}_{3}\right): \delta=31.61\left(\mathrm{~s}, \mathrm{PCy}_{3}\right)$.

$\left.\left[\left\{\eta^{6}-\mathrm{C}_{6} \mathrm{H}_{5}\left(\mathrm{CH}_{2}\right)_{3} \mathrm{OH}\right)\right\} \mathrm{RuCl}_{2}\left\{\mathbf{P}\left(\mathrm{CH}_{2} \mathrm{OH}\right)\right\}_{3}\right] \quad$ (1d): $\quad 134 \mathrm{mg}$ $(0.43 \mathrm{mmol})$ of $\left[\left\{\eta^{6}-\mathrm{C}_{6} \mathrm{H}_{5}\left(\mathrm{CH}_{2}\right)_{3} \mathrm{OH}\right\} \mathrm{RuCl}_{2}\right]$ (1a) was reacted with $50 \mathrm{mg}(0.40 \mathrm{mmol})$ of tris(hydroxymethyl)phosphine, $\mathrm{P}\left(\mathrm{CH}_{2} \mathrm{OH}\right)_{3}$, in $5 \mathrm{ml}$ of $\mathrm{CH}_{2} \mathrm{Cl}_{2}$. The reaction mixture was allowed to stir overnight and filtered by canula to remove some undissolved material. The vacuum dried residue was washed with $3 \times 2 \mathrm{ml}$ of $\mathrm{Et}_{2} \mathrm{O}$. After drying under vacuum $106 \mathrm{mg}$ (57\%) of a brown, hygroscopic powder was obtained. Analysis calcd. for $\mathrm{C}_{12} \mathrm{H}_{21} \mathrm{O}_{4} \mathrm{PRuCl}_{2}$ (432.2); $\mathrm{C}$ 31.68 (calc 33.34); H 5.34 (4.90) \%. $\mathrm{m}_{\mathrm{p}}=106{ }^{\circ} \mathrm{C}$.

${ }^{1} \mathrm{H}-\mathrm{NMR}\left(\mathrm{CD}_{3} \mathrm{OD}\right): \delta=1.93\left(\mathrm{~m}, 2 \mathrm{H}, \mathrm{CH}_{2} \mathrm{CH}_{2} \mathrm{CH}_{2}\right), 2.55(\mathrm{t}, J=7.8 \mathrm{~Hz}$, $\left.2 \mathrm{H}, \mathrm{PhCH} \mathrm{H}_{2}\right), 3.32\left(\mathrm{t},{ }^{3} J_{\mathrm{Il}-\mathrm{II}}=0.9 \mathrm{~Hz}, 3 \mathrm{H}, \mathrm{P}\left(\mathrm{CH}_{2} \mathrm{OH}\right)_{3}, 3 \mathrm{H}\right), 3.47\left(\mathrm{~d},{ }^{3} J_{\mathrm{HI}}\right.$ $\left.\mathrm{H}_{\mathrm{f}}=0.9 \mathrm{~Hz}, 6 \mathrm{H}, \mathrm{P}\left(\mathrm{CH}_{2} \mathrm{OH}\right)_{3}\right), 4.83(\mathrm{~s}, \mathrm{br}, \mathrm{OH}), 5.51(\mathrm{t}, J=6.8 \mathrm{~Hz}, 2 \mathrm{H})$, $5.62(\mathrm{dd}, J=6.8,4.6 \mathrm{~Hz}, 2 \mathrm{H}), 5.89(\mathrm{t}, J=4.6 \mathrm{~Hz}, 1 \mathrm{H}) \cdot{ }^{13} \mathrm{C} \mathrm{NMR}\left(\mathrm{CDCl}_{3}\right)$ : $\delta=30.19\left(\mathrm{~s}, \mathrm{CH}_{2}\right) 30.58\left(\mathrm{~s}, \mathrm{PhCH}_{2}\right), 57.38\left(\mathrm{~d}, \mathrm{~J}_{\mathrm{P}-\mathrm{C}}=64.2 \mathrm{~Hz}, \mathrm{P}\left(\mathrm{CH}_{2} \mathrm{OH}\right)_{3}\right)$, $72.74\left(\mathrm{~s}, \mathrm{CH}_{2} \mathrm{O}\right), 78.28,87.52(\mathrm{~s}, \mathrm{CH}), 88.70\left(\mathrm{~d},{ }^{2} \mathrm{~J}_{\mathrm{P}-\mathrm{C}}=5.3 \mathrm{~Hz}, \mathrm{CH}\right), 111.5$ $\left(\mathrm{d},{ }^{2} \mathrm{~J}_{\mathrm{P}-\mathrm{C}}=4.2, \mathrm{C}_{\mathrm{q}}\right) \cdot{ }^{31} \mathrm{P} \mathrm{NMR}\left(\mathrm{CDCl}_{3}\right): \delta=29.06\left(\mathrm{~s}, \mathrm{P}\left(\mathrm{CH}_{2} \mathrm{OH}\right)_{3}\right)$.

$\left.\left[\left\{\eta^{6}-\mathrm{C}_{6} \mathrm{H}_{5}\left(\mathrm{CH}_{2}\right)_{3} \mathrm{OH}\right)\right\} \mathbf{R u C l}\left(\mathbf{P}\left(\mathrm{CH}_{2} \mathrm{OH}\right)_{3}\right)_{2}\right]^{+} \quad \mathrm{Cl}^{-} \quad(\mathbf{1 e}): 0.052 \mathrm{~g}$ $(0.176 \mathrm{mmol})$ of $\left[\left\{\eta^{6}-\mathrm{C}_{6} \mathrm{H}_{5}\left(\mathrm{CH}_{2}\right)_{3} \mathrm{OH}\right\} \mathrm{RuCl}_{2}\right]_{2}$ was reacted with $45 \mathrm{mg}(0.36 \mathrm{mmol})$ of tris(hydroxymethyl)phosphine, $\mathrm{P}\left(\mathrm{CH}_{2} \mathrm{OH}\right)_{3}$, in $5 \mathrm{ml}$ of $\mathrm{CH}_{2} \mathrm{Cl}_{2}$. The reaction mixture was allowed to stir overnight and filtered by canula to remove some undissolved material. The filtered solution was dried in vacuo and the residue was washed with $3 \times 2 \mathrm{ml}$ of $\mathrm{Et}_{2} \mathrm{O}$. After removing of $\mathrm{Et}_{2} \mathrm{O}$ in vacuo $56 \mathrm{mg}$ $(59.3 \%)$ of 1e was obtained as a brown, waxy, hygroscopic solid. $\mathrm{C}_{15} \mathrm{H}_{30} \mathrm{Cl}_{2} \mathrm{O}_{7} \mathrm{P}_{2} \mathrm{Ru}$ (556.3).

'H-NMR ( $\left.\mathrm{CD}_{3} \mathrm{OD}\right): \delta=1.98\left(\mathrm{tt}, J=7.75,6.1 \mathrm{~Hz}, 2 \mathrm{H}, \mathrm{CH}_{2} \mathrm{CH}_{2} \mathrm{CH}_{2}\right), 2.48$ $\left(\mathrm{t}, J=7.75 \mathrm{~Hz}, 2 \mathrm{H}, \mathrm{PhCH}_{2}\right), 3.48\left(\mathrm{dt}, J=6.1,2.5 \mathrm{~Hz}, 2 \mathrm{H}, \mathrm{CH}_{2} \mathrm{O}\right), 4.07(\mathrm{~d}$ $J=2.5 \mathrm{~Hz}, 1 \mathrm{H}, \mathrm{OH}), 4.38\left(\mathrm{dd},{ }^{2} J_{\mathrm{PH}}=18.7,{ }^{2} J_{\mathrm{HH}}=11.6 \mathrm{~Hz}, 12 \mathrm{H}\right.$, $\left.\mathrm{P}\left(\mathrm{CH}_{2} \mathrm{OH}\right)_{3}\right), 4.82\left(\mathrm{~s}(\mathrm{br}), 6 \mathrm{H}, \mathrm{P}\left(\mathrm{CH}_{2} \mathrm{OH}\right)_{3}\right), 5.41(\mathrm{t}, J=5.9 \mathrm{~Hz}, 1 \mathrm{H}), 6.25$ $(\mathrm{d}, J=5.9 \mathrm{~Hz}, 2 \mathrm{H}), 6.58(\mathrm{t}, J=5.9 \mathrm{~Hz}, 2 \mathrm{H}) \cdot{ }^{13} \mathrm{C} \mathrm{NMR}\left(\mathrm{CDCl}_{3}\right): \delta=35.90$ $\left(\mathrm{s}, \mathrm{CH}_{2}\right) 37.40(\mathrm{~s}, \mathrm{PhCH}), 57.37\left(\mathrm{~d}, J_{\mathrm{P}-\mathrm{C}}=32.9 \mathrm{~Hz}, \mathrm{P}\left(\mathrm{CH}_{2} \mathrm{OH}\right)_{3}\right), 72.00(\mathrm{~s}$, $\left.\mathrm{CH}_{2} \mathrm{OH}\right), 78.72,87.08(\mathrm{~s}, \mathrm{CH}), 89.72\left(\mathrm{~d},{ }^{2} \mathrm{~J}_{\mathrm{P}-\mathrm{C}}=5.7 \mathrm{~Hz}, \mathrm{CH}\right)$, the $\mathrm{C}_{i p s o}$ quaternary carbon atom was not observed. ${ }^{31} \mathrm{P}$ NMR $\left(\mathrm{CDCl}_{3}\right): \delta=38.18$ (s, $\left.\mathrm{P}\left(\mathrm{CH}_{2} \mathrm{OH}\right)_{3}\right)$.

$\left.\left[\left\{\eta^{6}-\mathbf{C}_{6} \mathbf{H}_{5}\left(\mathrm{CH}_{2}\right)_{3} \mathrm{OMe}\right)\right\} \mathrm{RuCl}_{2}\right]_{2}$ (2a): Compound 2a was prepared analogously to $1 \mathrm{a}$ from $7.31 \mathrm{~g}(48.00 \mathrm{mmol})$ of $(1,4$-cyclohexadienyl)-1-propyl methyl ether and $1.97 \mathrm{~g}(8.27 \mathrm{mmol})$ of $\mathrm{RuCl}_{3}$ in $60 \mathrm{ml}$ of ethanol. The orange red solution was allowed to cool overnight at $4{ }^{\circ} \mathrm{C}$, which gave $\mathbf{2 a}$ as a crystalline solid. The mother liquor was removed by filtration and concentrated by distillation to $15 \mathrm{ml}$. A further crop of microcrystals was obtained by cooling this solution overnight in a fridge. The combined yield was $2.02 \mathrm{~g}$ (73.5\%). Analysis calcd. for $\mathrm{C}_{20} \mathrm{H}_{28} \mathrm{Cl}_{4} \mathrm{O}_{2} \mathrm{Ru}_{2}$ (644.4); $\mathrm{C} 37.43$ (calc 37.28); H $4.52(4.38) \% . m_{p}=245^{\circ} \mathrm{C}$.

'H-NMR $\left(\mathrm{CDCl}_{3}\right): \delta=1.81\left(\mathrm{tt}, J=7.2,5.9 \mathrm{~Hz}, 2 \mathrm{H}, \mathrm{CH}_{2} \mathrm{CH}_{2} \mathrm{CH}_{2}\right), 2.57(\mathrm{t}$, $\left.J=7.2 \mathrm{~Hz}, 2 \mathrm{H}, \mathrm{PhCH}_{2}\right), 3.22\left(\mathrm{~s}, 3 \mathrm{H}, \mathrm{OCH}_{3}\right), 3.32(\mathrm{l}, J=5.9 \mathrm{~Hz}, 2 \mathrm{H}$, $\left.\mathrm{CH}_{2} \mathrm{O}\right), 5.32(\mathrm{~d}, J=5.7 \mathrm{~Hz}, 2 \mathrm{H}), 5.55(\mathrm{t}, J=5.2 \mathrm{~Hz}, 1 \mathrm{H}), 5.63(\mathrm{dd}, J=5.7$, $5.2 \mathrm{~Hz}, 2 \mathrm{H}),{ }^{13} \mathrm{C} \mathrm{NMR}\left(\mathrm{CDCl}_{3}\right): \delta=29.76\left(\mathrm{~s}, \mathrm{CH}_{2}\right), 30.05\left(\mathrm{~s}, \mathrm{PhCH}_{2}\right), 58.90(\mathrm{~s}$ $\left.\mathrm{OCH}_{3}\right), 71.79\left(\mathrm{~s}, \mathrm{CH}_{2} \mathrm{O}\right), 80.17,80.86,84.37$ (each s, $\left.\mathrm{CH}\right), 101.41\left(\mathrm{C}_{\mathrm{q}}\right)$. 
$\left.\mid\left\{\eta^{6}-\mathrm{C}_{6} \mathrm{H}_{5}\left(\mathrm{CH}_{2}\right)_{3} \mathbf{O C H}_{3}\right\} \mathbf{R u}\left(\mathrm{P}^{i} \mathrm{Pr}_{3}\right) \mathrm{Cl}_{2}\right](\mathbf{2 b}): 0.20 \mathrm{~g}(0.31 \mathrm{mmol})$ of $\mathbf{1}$ was reacted with $237 \mu \mathrm{l}(0.62 \mathrm{mmol})$ of $\mathrm{P}^{2} \mathrm{Pr}_{3}$ in $8 \mathrm{ml}$ of $\mathrm{CH}_{2} \mathrm{Cl}_{2}$. The reaction mixture was stirred overnight at room temperature and filtered via a paper-tipped cannula. The solvent was then removed under vacuum and the dry residue was washed with $3 \times 4 \mathrm{ml}$ of $\mathrm{Et}_{2} \mathrm{O}$. The solid was then vacuum dried to yield $254 \mathrm{mg}$ of $\mathbf{2 b}$ (85\%). Analysis calcd. for $\mathrm{C}_{19} \mathrm{H}_{35} \mathrm{Cl}_{2} \mathrm{OPRu}$ (482.4); $\mathrm{C} 47.34$ (calc 47.30); H $7.30(7.31) \% . m_{p}=117^{\circ} \mathrm{C}$.

'H-NMR $\left(\mathrm{CDCl}_{3}\right): \delta=1.29,1.34$ (each d, $J=7.2 \mathrm{~Hz}, 9 \mathrm{H}, \mathrm{CH}_{3}\left(\mathrm{P}^{\prime} \operatorname{Pr}_{3}\right)$ ), $1.93\left(\mathrm{tt}, J=7.3,6.2 \mathrm{~Hz}, 2 \mathrm{H}, \mathrm{CH}_{2} \mathrm{CH}_{2} \mathrm{CH}_{2}\right), 2.71(\mathrm{t}, J=7.3 \mathrm{~Hz}, 2 \mathrm{H}$, $\left.\mathrm{PhCH} H_{2}\right), 2.82\left(\mathrm{~m}, \mathrm{CH}\left(\mathrm{P}^{\prime} \mathrm{Pr}_{3}\right), 3 \mathrm{H}\right), 3.30\left(\mathrm{~s}, 3 \mathrm{H}, \mathrm{OCH} \mathrm{H}_{3}\right), 3.47(\mathrm{t}, J=6.2 \mathrm{~Hz}$ $\left.2 \mathrm{H}, \mathrm{CH}_{2} \mathrm{O}\right), 5.36(\mathrm{t}, J=5.4 \mathrm{~Hz}, 2 \mathrm{H}), 5.40(\mathrm{~d}, J=5.0 \mathrm{~Hz}, 2 \mathrm{H}), 5.58(\mathrm{dd}$ $J=5.4,5.0 \mathrm{~Hz}, 1 \mathrm{H}) \cdot{ }^{13} \mathrm{C} \operatorname{NMR}\left(\mathrm{CDCl}_{3}\right): \delta=20.53\left(\mathrm{~s}, \mathrm{CH}_{3}\left(\mathrm{P}^{\prime} \mathrm{Pr}_{3}\right), 25.94(\mathrm{~d}\right.$, $J_{\mathrm{P}-\mathrm{C}}=20.5 \mathrm{~Hz}, \mathrm{CH}\left(\mathrm{P}^{\prime} \mathrm{Pr}_{3}\right), 29.52\left(\mathrm{~s}, \mathrm{CH}_{2}\right), 30.16\left(\mathrm{~s}, \mathrm{PhCH}_{2}\right), 58.86(\mathrm{~s}$, $\left.\mathrm{OCH}_{3}\right), 72.15\left(\mathrm{~s}, \mathrm{CH}_{2} \mathrm{O}\right), 77.05,87.89(\mathrm{~s}, \mathrm{CH}), 88.47\left(\mathrm{~d}, 2 J_{\mathrm{p} . \mathrm{C}}=5.0 \mathrm{~Hz}\right.$ $\mathrm{CH}), 112.39\left(\mathrm{C}_{\mathrm{q}}\right) .{ }^{31} \mathrm{P}$ NMR $\left(\mathrm{CDCl}_{3}\right): \delta=41.45\left(\mathrm{~s}, \mathrm{P} \mathrm{Pr}_{3}\right)$.

$\left.\left[\left\{\mathrm{C}_{6} \mathrm{H}_{5}\left(\mathrm{CH}_{2}\right)_{3} \mathrm{OCH}_{3}\right)\right\} \mathbf{R u}\left(\mathrm{PCy}_{3}\right) \mathrm{Cl}_{2}\right]$ (2c): Compound 2a (0.100 g, $0.150 \mathrm{mmol})$ and $0.103 \mathrm{~g}(0.31 \mathrm{mmol})$ of $\mathrm{PCy}_{3}$ were dissolved in $4 \mathrm{ml}$ of $\mathrm{CH}_{2} \mathrm{Cl}_{2}$ and stirred overnight. The filtered solution was dried under vacuum and the residue was washed with $3 \mathrm{I}>4 \mathrm{ml}$ of $\mathrm{Et}_{2} \mathrm{O}$ and dried. Compound $2 \mathrm{c}$ was obtained as an orange brown fluffy powder in a yield of $130 \mathrm{mg}(72 \%)$. Analysis calcd. for $\mathrm{C}_{28} \mathrm{H}_{47} \mathrm{Cl}_{2} \mathrm{OPRu}$ (602.6); C 56.00 (calc 55.81); $\mathrm{H} 8.15$ (7.86) \%. $\mathrm{m}_{\mathrm{p}}=234^{\circ} \mathrm{C}$.

${ }^{1} \mathrm{H}-\mathrm{NMR}\left(\mathrm{CDCl}_{3}\right): \delta=1.26(\mathrm{~m}(\mathrm{br}), 12 \mathrm{H}), 1.41(\mathrm{t}, J=12.2 \mathrm{~Hz}, 3 \mathrm{H}), 1.76$ $(\mathrm{m}(\mathrm{br}), 9 \mathrm{H}), 2.1(\mathrm{~m}, 6 \mathrm{H}), 2.42(\mathrm{~m}, 3 \mathrm{H})$, all $\mathrm{CH}_{2}, \mathrm{CH}\left(\mathrm{PCy}_{3}\right), 1.94(\mathrm{tt}, J=$ $\left.7.8,6.4 \mathrm{~Hz}, 2 \mathrm{H}, \mathrm{CH}_{2} \mathrm{CH}_{2} \mathrm{CH}_{2}\right), 2.65(\mathrm{t}, J=7.8 \mathrm{~Hz}, 2 \mathrm{H}, \mathrm{PhCH}), 3.31$ (s, $\left.3 \mathrm{H}, \mathrm{OCH}_{3}\right), 3.45\left(\mathrm{t}, J=6.4 \mathrm{~Hz}, 2 \mathrm{H}, \mathrm{CH}_{2} \mathrm{O}\right), 5.37(\mathrm{~m}, 3 \mathrm{H}), 5.57(\mathrm{~m}, 2 \mathrm{H})$. ${ }^{1.3} \mathrm{C} \operatorname{NMR}\left(\mathrm{CDCl}_{3}\right): \delta=26.8\left(\mathrm{~d}, J_{\mathrm{PC}}=1.05 \mathrm{~Hz}, \mathrm{CH}_{2}\right), 27.9,28.1\left(\mathrm{~s}, \mathrm{CH}_{2}\right)$, $29.5\left(\mathrm{~d},{ }^{5} J_{\mathrm{P}-\mathrm{C}}=1.05 \mathrm{~Hz}, \mathrm{CH}_{2}\right), 30.2\left(\mathrm{~d},{ }^{4} J_{\mathrm{P}-\mathrm{C}}=2.1 \mathrm{~Hz}, \mathrm{PhCH}_{2}\right), 36.3(\mathrm{~d}$ $\left.{ }^{1} J_{\mathrm{PC}}=18.9 \mathrm{~Hz}, \mathrm{CH}\left(\mathrm{PCy}_{3}\right)\right), 58.65\left(\mathrm{~s}, \mathrm{CH}_{2} \mathrm{O}\right), 72.0\left(\mathrm{~s}, \mathrm{OCH}_{3}\right), 77.45,77.5$, $85.6(\mathrm{~s}, \mathrm{CH}), 88.3\left(\mathrm{~d},{ }^{2} J_{\mathrm{P}-\mathrm{C}}=5.3 \mathrm{~Hz}, \mathrm{CH}\right), 111.9\left(\mathrm{~d},{ }^{2} J_{\mathrm{P}-\mathrm{C}}=5.8 \mathrm{~Hz}, \mathrm{C}_{\mathrm{q}}\right)$. ${ }^{31}$ P NMR $\left(\mathrm{CDCl}_{3}\right): \delta=32.91\left(\mathrm{~s}, \mathrm{PCy}_{3}\right)$.

$\left.\left[\left\{\eta^{6}-\mathbf{C}_{6} \mathbf{H}_{5}\left(\mathbf{C H}_{2}\right)_{2} \mathrm{OH}\right)\right\} \mathbf{R u C l}_{2}\right]$ (3a): In a typical run, $3.60 \mathrm{~g}$ $(29.03 \mathrm{mmol})$ of 2-(1,4-cyclohexadienyl)ethanol was reacted with $1.20 \mathrm{~g}(5.03 \mathrm{mmol})$ of $\mathrm{RuCl}_{3}$ in $20 \mathrm{ml}$ of ethanol. The reaction mixture was heated under reflux for $6 \mathrm{~h}$ and the solution was left to cool down overnight in a fridge. Ethanol was removed by cannula filtration and the microcrystalline solid was recrystallized by slowly cooling a hot solution in ethanol. After drying under vacuum, $1.09 \mathrm{~g}(73.7 \%)$ were obtained as orange microcrystals. Analysis calcd. for $\mathrm{C}_{8} \mathrm{H}_{10} \mathrm{Cl}_{2} \mathrm{ORu}$ (294.1); C 33.16 (calc 32.67); $\mathrm{H} 3.46$ (3.43) $\% . \mathrm{m}_{\mathrm{p}}=211^{\circ} \mathrm{C}$.

'H-NMR (dmf-d $\left.{ }_{7}\right): \delta=2.57\left(\mathrm{t}, J=6.0 \mathrm{~Hz}, 2 \mathrm{H}, \mathrm{PhCH}_{2}\right), 3.70$ (dt, $J=6.0$, $\left.5.4 \mathrm{~Hz}, 2 \mathrm{H}, \mathrm{CH}_{2} \mathrm{O}\right), 4.66(\mathrm{1}, J=5.4 \mathrm{~Hz}, 1 \mathrm{H}, \mathrm{OH}), 5.46(\mathrm{~m}, 3 \mathrm{H}), 5.61(\mathrm{t}, J=$ $5.6 \mathrm{~Hz}, 2 \mathrm{H}) ;{ }^{1} \mathrm{H}-\mathrm{NMR}\left(\right.$ dmso-d $\left._{6}\right): \delta=2.56\left(\mathrm{t}, J=6.1 \mathrm{~Hz}, 2 \mathrm{H}, \mathrm{CH}_{2} \mathrm{O}\right), 3.66$ $\left(\mathrm{br}, 2 \mathrm{H}, \mathrm{CH}_{2} \mathrm{O}\right), 4.75(\mathrm{br}, 1 \mathrm{H}, \mathrm{OH}), 5.76(\mathrm{~m}, 3 \mathrm{H}), 5.96(\mathrm{t}, J=5.9 \mathrm{~Hz}, 2 \mathrm{H})$; ${ }^{13} \mathrm{C}^{\mathrm{N}} \mathrm{NMR}\left(\mathrm{dmf}-\mathrm{d}_{7}\right): \delta=37.0\left(\mathrm{~s}, \mathrm{CH}_{2}\right), 61.0\left(\mathrm{~s}, \mathrm{OCH}_{2}\right), 78.0,80.9,84.0$ (each s, $\mathrm{CH}), 98.6\left(\mathrm{C}_{\mathrm{n}}\right)$.

$\left.\mid\left\{\eta^{6}-\mathrm{C}_{6} \mathrm{H}_{5}\left(\mathrm{CH}_{2}\right)_{2} \mathrm{OH}\right\} \mathrm{Ru}\left(\mathrm{P}^{i} \mathrm{Pr}_{3}\right) \mathrm{Cl}_{2}\right]$ (3b): A suspension of $0.175 \mathrm{~g}$ $(0.59 \mathrm{mmol})$ of $3 \mathrm{a}$ in $7 \mathrm{ml}$ of $\mathrm{CH}_{2} \mathrm{Cl}_{2}$ was treated with $112.5 \mu \mathrm{l}$ $(0.59 \mathrm{mmol})$ of $\mathrm{P}^{i} \mathrm{Pr}_{3}$. After stirring overnight, the reaction mixture had turned into a brown solution. Small quantities of undissolved material were removed by cannula filtration. The filtered solution was dried in vacuo and the residue was washed with $3 \times 4 \mathrm{ml}$ of $\mathrm{Et}_{2} \mathrm{O}$ and vacuum dried. Compound $\mathbf{3 b}$ was obtained as a brown solid in a yield of $220 \mathrm{mg}(82 \%)$. Analysis calcd. for $\mathrm{C}_{17} \mathrm{H}_{31} \mathrm{Cl}_{2} \mathrm{O}$ $\mathrm{PRu}$ (454.4); C 45.28 (calc 44.94); H 7.02 (6.88) \%. $\mathrm{m}_{\mathrm{p}}=121^{\circ} \mathrm{C}$.

${ }^{1} \mathrm{H}-\mathrm{NMR}\left(\mathrm{CD}_{2} \mathrm{Cl}_{2}\right): \delta=1.29$ and 1.36 (each d, $J=7.2 \mathrm{~Hz}, 9 \mathrm{H}, \mathrm{CH}_{3}\left(\mathrm{P}^{1} \mathrm{Pr}_{3}\right.$ ), $2.72\left(\mathrm{~m}, 3 \mathrm{H}, \mathrm{CH}\left(\mathrm{P}^{i} \mathrm{Pr},\right)\right), 2.84\left(\mathrm{t}, J=5.7 \mathrm{~Hz}, 2 \mathrm{H}, \mathrm{PhCH}_{2}\right), 4.07(\mathrm{t}, J=$ $\left.5.7 \mathrm{~Hz}, 2 \mathrm{H}, \mathrm{CH}_{2} \mathrm{O}\right), 5.31(\mathrm{~m}, 3 \mathrm{H}), 5.76(\mathrm{~m}, 2 \mathrm{H}),{ }^{13} \mathrm{C} \mathrm{NMR}\left(\mathrm{CD}_{2} \mathrm{Cl}_{2}\right): 8=$ $21.77\left(\mathrm{~d},{ }^{3} \mathrm{~J}_{\mathrm{P}-\mathrm{C}}=1.8 \mathrm{~Hz}, \mathrm{CH}_{3}\left(\mathrm{P}^{\prime} \mathrm{Pr}_{3}\right)\right), 27.74\left(\mathrm{~d}, J_{\mathrm{P}-\mathrm{C}}=20.4 \mathrm{~Hz}, \mathrm{CH}\left(\mathrm{P}^{\prime} \mathrm{Pr}_{3}\right)\right)$, $31.51\left(\mathrm{~s}, \mathrm{CCH}_{2}\right), 62.13\left(\mathrm{~s}, \mathrm{CH}_{2} \mathrm{O}\right), 80.12,84.79(\mathrm{~s}, \mathrm{CH}), 92.31\left(\mathrm{~d},{ }^{2} \mathrm{~J}_{\mathrm{PCC}}=\right.$ $4.7 \mathrm{~Hz}, \mathrm{CH}), 110.89\left(\mathrm{C}_{\mathrm{q}},{ }^{2} \mathrm{~J}_{\mathrm{p}-\mathrm{C}}=4.8 \mathrm{~Hz}\right),{ }^{31} \mathrm{P} \operatorname{NMR}\left(\mathrm{CDCl}_{3}\right): \delta=41.25$ (s, $\left.P^{\prime} \operatorname{Pr}_{3}\right)$.
The single crystal structures of $\mathbf{1 a}$ and $\mathbf{2 a}$ were determined on a Bruker-Nonius Kappa CCD diffractometer and solved and refined with the program package SHELX-97 [35]. A numerical absorption correction was carried out for both crystals with the program HABITUS [37]. The packing plot of compound 1a was obtained with the program MERCURY $[38,39]$. Crystallographic data for 1a (CCDC 284428) and 2a (CCDC 284429) have been deposited at the Cambridge Crystallographic Data Centre and can be obtained free of charge via www.ccdc.cam.ac.uk/conts/retrieving.html or from the Cambridge Crystallographic Data Centre, 12 Union Road, Cambridge CB2 1EZ, UK; fax (+44) 1223-336-033, or at deposit@ccdc.cam.ac.uk.

Acknowledgement. We thank Dr. Rainer Ruf for his aid in the structure refinement. Financial support of this work by the Deutsche Forschungsgemeinschaft (grant WI 1262/4-1) is gratefully acknowledged.

\section{References}

[1] P. D. Smith, A. H. Wright, J. Orgnanomet. Chem. 1998, 559, 141.

[2] A. Fürstner, M. Liebl, C. W. Lehmann, M. Picquet, R. Kunz, C. Bruneau, D. Touchard, P. H. Dixneuf, Chem. Eur. J. 2000, $6,1847$.

[3] K. Y. Ghebreyessus, J. F. Nelson, Organometallics 2000, 19, 3387.

[4] M. A. Bennett, A. J. Edwards, J. R. Harper, T. Khimyak, A. C. Willis, J. Organomet. Chem. 2001, 629, 7.

[5] P. D. Smith, T. Gelbrich, M. B. Hursthouse, J. Organomet. Chem. 2002, 659, 1.

[6] J. F. Nelson, K. G. Ghebreyessus, V. C. Cook, A. J. Edwards, W. Wielandt, S. B. Wild, A. C. Willis, Organometallics 2002, 1727.

[7] J. W. Faller, D. G. D. Alessi, Organometallics 2003, 22, 2749.

[8] K. Umezawa-Vizzini, I. Y. Guzman-Jimenez, K. H. Whitmire, T. R. Lee, Organometallics 2003, 22, 3059.

[9] P. Pinto, G. Marconi, F. W. Heinemann, U. Zenneck, Organometallics 2004, 23, 374.

[10] K. Umezawa-Vizzini, T. R. Lee, Organometallics 2003, 22, 3066.

[11] K. Umezawa-Vizzini, T. R. Lee, Organometallics 2004, 23, 1448.

[12] J. Soleimannejad, C. White, Organometallics 2005, 24, 2538.

[13] T. Ohnishi, Y. Miyaki, H. Asano, H. Kurosawa, Chem. Lett. 1999, 810.

[14] Y. Miyaki, T. Onishi, H. Kurosawa, Inorg. Chim. Acta 2000, 300-302, 369.

[15] Y. Miyaki, T. Onishi, S. Ogoshi, H. Kurosawa, J. Organomet Chem. 2000, 616, 135.

[16] B. Therrien, L. Vieille-Petit, J. Jeanette-Gris, P. Stepnicka, G. Süss-Fink, J. Organomet. Chem. 2004, 689, 2456.

[17] J. Cubrilo, R. F. Winter, D. Gudat, Chem. Commun. 2005, 510.

[18] M. A. Bennett, T.-N. Huang, T. W. Matheson, A. K. Smith, S. Ittel, W. Nickerson, Inorg. Synth. 1980, 21, 75.

[19] A. J. Birch, J. Chem. Soc. 1950, 1551.

[20] R. A. Zelonka, M. C. Baird, Can. J. Chem. 1972, 50, 3063.

[21] D. R. Robertson, T. A. Stephenson, T. Arthur, J. Organomet. Chem. 1978, 162, 121.

[22] F. B. McCormick, D. C. Cox, W. B. Gleason, Organometallics $1993,12,610$ 
[23] F. B. McCormick, W. B.Gleason, Acta Crystallogr. 1988, C44, 603 .

[24] C. S. Allardyce, P. J. Dyson, D. J. Ellis, P. A. Salter, R. Scopiletti, J. Organomet. Chem. 2003, 668, 35.

[25] T. Steiner, Angew. Chem. 2002, 114, 50; Angew. Chem. Int. Ed. 2002, $41,48$.

[26] L. J. Higham, M. K. Whittlesey, P. T. Wood, Dalton Trans. 2004, 4204.

[27] T. Naota, H. Takaya, S.-I. Murahashi, Coord. Chem. Rev. 1998, 98, 2599.

[28] F. Simal, A. Demonceau, A. F. Noels, Angew. Chem. 1999, 111, 559; Angew. Chem. Int. Ed. Engl. 1999, 38, 538.

[29] M. Picquet, D. Touchard, C. Bruneau, P. H. Dixneuf, New. J. Chem. 1999, 141.
[30] A. Fürstner, A. F. Hill, M. Liebl, J. D. E. T. Wilton-Ely, Chem. Commun. 1999, 601.

[31] S. Jung, K. Ilg, C. D. Brandt, J. Wolf, H. Werner, Dalton Trans. 2002, 318.

[32] P. Lahuerta, J. Latorre, J. Soto, Y. Mugnier, Polyhedron 1989 , 8, 2803.

[33] U. Kölle, R. Görissen, A. Hörnig, Inorg. Chim. Acta 1994 $218,33$.

[34] D. Devanne, P. H. Dixneuf, J. Organomet. Chem. 1990, 390, 371.

[35] G. M. Sheldrick, SHELX-97, Program for Crystal Structure Solution and Refinement; G. M. Sheldrick, Ed.; Institut für Anorganische Chemie der Universität, Tammannstraße 4: Göttingen, 1997. 